\title{
LABORATORY MANUAL OF ACRICULTURAL CHEMISTRY
}

HEDGES AND BRYANT 


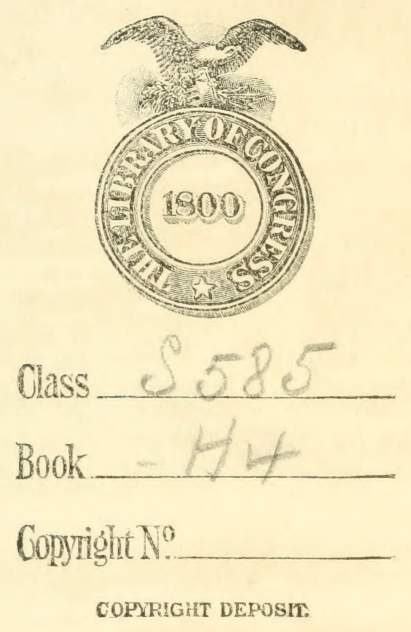







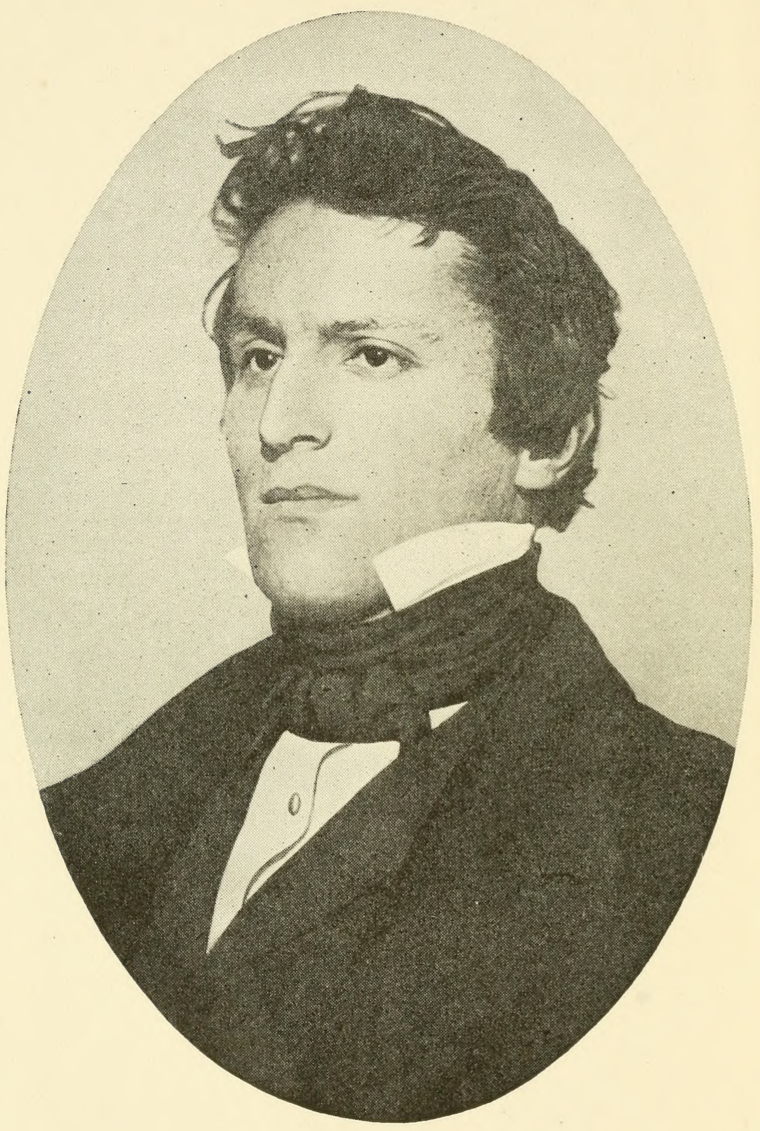

PROFESSOR S. W. JOHNSON 


\title{
LABORATORY MANUAL OF AGRICULTURAL CHEMISTRY
}

\author{
BY \\ CHARLES CLEVELAND HEDGES, Рн.D. \\ PROFESSOR OF AGRICULTURAL CHEMISTRY AND HEAD OF THE \\ DEPARTMENT OF CHEMISTRY AND CHEMICAL ENGINEERING \\ TEXAS AGRICULTURAL AND MECHANICAL COLLEGE
}

AND

WILLTAM THOREAU BRYANT, B.S., Сн.E. INSTRUCTOR IN AGRICULTURAL CHEMISTRY TEXAS AGRICULTURAL AND MECHANICAL COLLEGE

GINN AND COMPANY

BOSTON - NEW YORK - CHICAGO - LONDON atlanta - DAllas - COLUMbUS - SAN FRANCisco 


\section{5 \\ $\mathrm{H}_{4}$}

COPYRIGHT, 1916, BY

CHARLES CLEVELAND HEDGES AND

WILLIAM THOREAU BRYANT

ALL RIGHTS RESERVED

516.8

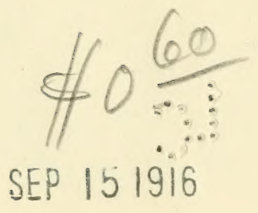

שbe Atben aum 月ress

GINN AND COMPANY + PRO-

PRIETORS · BOSTON • U.S.A.

(C) Cl. A438374

$2-20$ 


\section{PREFACE}

This Laboratory Manual is the outgrowth of several years' experience in agricultural institutions in teaching chemistry in its various relations to agriculture. The directions are designed as a laboratory guide for students in agricultural chemistry. It is necessary that this course be preceded by a course in general or inorganic chemistry and accompanied by a course in the theory of agricultural chemistry. A course in quantitative analysis is not necessarily a prerequisite. At the beginning of the Manual, along with the preparation of standard solutions used later in the analysis of agricultural products, a few experiments in quantitative analysis have been given to illustrate the fundamental principles and more important methods of manipulation. Directions as to the setting up of apparatus, details of manipulation, use and care of the balance, chemistry, and stoichiometry should be given in lectures accompanying the laboratory practice. The authors did not consider it advisable to burden the laboratory guide with a large amount of explanatory notes giving reasons for each step in the directions. It was thought that this could be accomplished to better advantage by means of lectures accompanying the laboratory work, and by questions at the end of each experiment that are designed to encourage the student to think for himself and to do outside reading. This arrangement gives the teacher an opportunity to

$$
\text { [v] }
$$


present the theory in any particular manner he may desire and to come in closer contact with the students, thereby making the practice more interesting to them by the personal contact. The directions for each experiment are simplified, as far as it is considered advisable, in order that the student might be able to pursue the laboratory work with the least possible assistance from the teacher. In the Appendix is given a list of some of the most important works bearing on this subject so as to further the interest of the student by encouraging outside reading.

In preparing this Manual free use has been made of standard works on quantitative analysis, of the publications of the Association of Official Agricultural Chemists, and of the bulletins of the Bureau of Chemistry, United States Department of Agriculture. The authors desire to acknowledge their obligation to the "Letter-Files" and to the Yale University Press for the portrait of Professor S. W. Johnson used as the frontispiece.

C. C. HEDGES

College Station, Texas W. T. BRYANT 


\section{CONTENTS}

PART I. PREPARATORY QUANTITATIVE ANALYSIS

ExPERIMENT

PAGL

Introduction . . . . . . . . . . . . . . . . 1

1. Preparation of Cleaning Mixture . . . . . . . . . 2

2. Preparation of an Aproximate $\mathrm{N} / 10 \mathrm{NaOH}$ Solution . . 3

3. Preparation of an Approximate $\mathrm{N} / 5 \mathrm{HCl}$ Solution . . . 3

4. Determination of Equivalent Volumes . . . . . . . 4

5. I. Preparation of a Perforated or Gooch Crucible . . . 6

II. Staudardization of HCl Solution hy Gravimetric Method 8

6. I. Standardization of the $\mathrm{HCl}$ Solution by Volumetric Method . . . . . . . . . . . . . 10

II. Calculation of the Titre of the NaOH Solution . . . 12

7. Determination of the Strength of an Unknown Alkali Solution . . . . . . . . . . . . . . . 12

8. Determination of the Strength of an L'nknown Acid Solution

9. Determination of the Strength of an Unknown $\mathrm{K}_{2} \mathrm{CO}_{3}$ Solution, using Methyl Orange as Indicator . . . . . 13

10. Determination of the Strength of an Unknown $\mathrm{K}_{2} \mathrm{CO}_{3}$ Solution, using Phenolphthalein as Indicator . . . . . 13

11. Determination of the Strength of an Unknown $\mathrm{NaOH}$ and $\mathrm{Na}_{2} \mathrm{CO}_{3}$ Solution . . . . . . . . . . . 14

12. Determination of Acetic Acid in Vinegar . . . . . . 15

13. Determination of Total Solids in Vinegar . . . . . . 16

14. Determination of Ash in Vinegar . . . . . . . . 16

15. Preparation of Standard Potassium Permanganate Solution $\left(\mathrm{KMnO}_{4}\right)$. . . . . . . . . . . . . . . 17

16. Determination of the Amount of Calcium Oxide in Limestone 18 
Preparation of a Sample of Feedstuff for Analysis . . . 21

17. Determination of Moisture in Feedstuffs . . . . . . . 21

18. Determination of Ash in Feedstuffs . . . . . . . . 22

19. Determination of Crude Protein in Feedstuffs . . . . 23

20. Determination of Ether Extract (Fat) in Feedstuffs . 26

21. Preparation of a 1.25 Per Cent $\mathrm{H}_{2} \mathrm{SO}_{4}$ Solution and a 1.25

Per Cent $\mathrm{NaOH}$ Solution . . . . . . . . . . 28

22. Determination of Crude Fiber in Feedstuffs . . . . . 29

23. Determination of Nitrogen-Free Extract in Feedstuffs . . 30

PART III. CHEMICAL ANALYSIS OF SOIL

Directions for taking a Sample of Soil for Analysis . . . 32

Preparation of Samples for Analysis . . . . . . . . 33

24. Qualitative Analysis of Soil . . . . . . . . . . 34

25. Determination of Moisture in Soil . . . . . . . . . 35

26. Determination of Volatile Matter in Soil . . . . . . 36

27. Determination of Humus in Soil . . . . . . . . . 36

28. Determination of Nitrogen in Soil (Nitrates Absent) . . 37

29. Test for Acidity or Alkalinity of Soil and Determination of

Lime Requirements . . . . . . . . . . . 38

30. Strong Hydrochloric Acid (sp. gr. 1.115) Digestion of Soil.

Preparation of Soil Solution . . . . . . . . . 39

31. Determination of Iron (Fe) in Soil Solution by Volumetric

Method . . . . . . . . . . . . . 41

32. Determination of Calcium (Ca) in Soil Solution by Volumetric Method . . . . . . . . . . . . . 42

33. Determination of Phosphoric Acid $\left(\mathrm{P}_{2} \mathrm{O}_{5}\right)$ in Soil Solution by Gravimetric Method . . . . . . . . . . .

33 a. Determination of Phosphoric Acid $\left(\mathrm{P}_{2} \mathrm{O}_{5}\right)$ in Soil Solution

by Volumetric Method (Optional Method) . . . .

34. Determination of Potash $\left(\mathrm{K}_{2} \mathrm{O}\right)$ in Soil Solution by the Use of Platinum Solution . . . . . . . . . . 47

$34 a$. Determination of Potash $\left(\mathrm{K}_{2} \mathrm{O}\right)$ in Soil Solution by

Volumetric Method (Optional Method) .

$34 b$. Determination of Potash $\left(\mathrm{K}_{2} \mathrm{O}\right)$ in Soil Solution by the

Use of Platinum Solution (Moore's Method modified) (Optional Method). 
Preparation of Sample of Fertilizer for Analysis . . . . 5. 5

35. Determination of Moisture in Fertilizer . . . . . . . 5.

36. Preparation of a Standard NaOI Solution for Phosphoric Acid $\left(\mathrm{P}_{2} \mathrm{O}_{5}\right)$ Determination . . . . . . . . . 56

37. Determination of Total Phosphoric Acid $\left(\mathrm{P}_{2} \mathrm{O}_{5}\right)$ in Fertilizer 57

38. Determination of Water-Soluble Phosphoric Acid $\left(\mathrm{P}_{2} \mathrm{O}_{5}\right)$ in Fertilizer . . . . . . . . . . . . . 59

39. Determination of Citrate-Soluble Phosphoric Acid $\left(\mathrm{P}_{2} \mathrm{O}_{5}\right)$ in Fertilizer . . . . . . . . . . . . . . . 59

40. Determination of Potash $\left(K_{2} \mathrm{O}\right)$ in a Mixed Fertilizer by the use of Platinum Solution

40 a. Determination of Potash $\left(\mathrm{K}_{2} \mathrm{O}\right)$ in a Mixed Fertilizer by Volumetric Method (Optional Method)

41. Determination of Nitrogen in Fertilizers (Nitrates Present)

PART V. ANALYSIS ()F INSECTICIDE AND FLNGICIDE

42. Preparation and Standardization of Solution for Determination of Arsenious Oxide $\left(\mathrm{As}_{2} \mathrm{O}_{3}\right)$ in Paris Green

43. Determination of Total Arsenious Oxide $\left(\mathrm{As}_{2} \mathrm{O}_{3}\right)$ in Paris Green .

44. Determination of Water-Soluble Arsenious Oxide $\left(\mathrm{As}_{2} \mathrm{O}_{3}\right)$ in Paris Green . . . . . . . . . . . . 66

45. Determination of Moisture in Lead Arsenate . . . . . 67

46. Determination of Total Lead Oxide in Lead Arsenate . . 67

47. Determination of Water-Soluble Lead Oxide in Lead

Arsenate . . . . . . . . . . . . . . 68

48. Determination of Total Arsenic Oxide $\left(\Lambda_{s_{2}}()_{5}\right)$ in Lead Arsenate . . . . . . . . . . . . . 69

49. Determination of Water-Soluble Arsenic Oxide $\left(\mathrm{As}_{2} \mathrm{O}_{5}\right)$ in Lead Arsenate . . . . . . . . . . . . . 70 50. Testing Bordeaux Mixture for Soluble Copper . . . . . 70

\section{PART VI. ANALYSIS OF MILK}

51. Determination of Specific Gravity of Milk . . . . . . 72 52. Determination of Total Solids in Milk . . . . . . . 73 53. Determination of Ash in Milk . . . . . . . . . 73 
54. Determination of Fat in Milk by the Werner-Schmidt Method . . . . . . . . . . . . . 74

5.5. Determination of Total Protein (Casein and Albumin) in Milk . . . . . . . . . . . . . 75 56 . Determination of Casein in Milk . . . . . . . 75

PART VII. A BRIEF SANITARY EXAMINATION OF WATER

57. Determination of Total Solids in Water . . . . . . . 77

58. Determination of Chlorine as Chlorides in Water . . . . 77

59. Detection of Free Ammonia in Water . . . . . . . . 78

60. Detection of Nitrites in Water . . . . . . . . . . 79

61. Detection of Nitrates in Water . . . . . . . . . . 79

62. Determination of Absorbed Oxygen in Water . . . . . 80

63. Determination of Temporary Harduess or Alkalinity of

Water. . . . . . . . . . . 80

PAR'T VIII. APPENDIX

Books of Referenee . . . . . . . . . . . . . . 82

Tathles of Wrights. . . . . . . . . . . . . . 8:3

Tables of Measures . . . . . . . . . . . . . 84

Strength of IICl solution at I)ifferent I)ensities, 15 C. . . . . \$5

Strength of $\mathrm{H}_{2} \mathrm{SO}_{4}$ Solution at Different Densities, $15^{\circ} \mathrm{C}$. . $\quad$. 85

Strength of $\mathrm{HNO}_{3}$ Solution at Different Densities, $15^{\circ} \mathrm{C}$. . $\quad$. 86

Strength of $\mathrm{NH}_{4} \mathrm{OII}$ Solution at Different Densities, 15) C. . . 86

Strength of NaOII Solution at Different Deusities, 15 C. . . 87

Rules to determine Solubilities in Water . . . . . . . 88

Directions for Preparation of Reagents. . . . . . . . 88

Apparatus for Desk Equipment . . . . . . . . . . . 93

International Atomic Weights (1916) . . . . . . . . 94 
LABORATORY MANUAL OF AGRICULTURAL CHEMISTRY 


\title{
LABORATORY MANUAL OF AGRICULTURAL CHEMISTRY
}

\author{
PART I
}

\section{PREPARATORY QUANTITATIYE ANALYSIS}

\section{INTRODUCTION}

At the first laboratory period the student should check up the apparatus in the desk assigned to him and immediately report any shortage or broken apparatus to the instructor in charge. Each student should be required to turn in at the end of the term's work a desk fully equipped with a complete set of appraratus in perfect condition. He should also be required to make a wash bottle to be used in the analytical work, and have it inspected by the instructor. All records of the laboratory work should be recorded in a notebook in a neat and systematic manner.

Reports of experiments and answers to all questions should be submitted at the next period, after the experiment is completed. Cleanliness, neatness, patience, and the most careful attention to details of the directions cannot be overemphasized in laboratory manipulations. 



\section{Experiment No. 1}

\section{PREPARA'TION OF CLEANING MIXTURE}

Dissolve $20 \mathrm{~g}$. of commercial $\mathrm{K}_{2} \mathrm{Cr}_{2} \mathrm{O}_{7}$ in $75 \mathrm{cc}$. of warm water, cool, and pour slowly into it, with constant stirring, 115 ce. of commercial sulphuric acid $\left(\mathrm{H}_{2} \mathrm{SO}_{4}\right)$. The potassium dichromate solution should be placed in a No. 7 evaporating dish, if convenient, before pouring the sulphuric acid into it. When the solution is completely cooled, it should be transferred to a $250 \mathrm{cc}$. widle-mouthed bottle. (Be careful in making this mixture, so as not to spill it on your clothes.) Invert the burettes in the cleaning mixture, attach the rubber tubing, draw up to the $50 \mathrm{ce}$. mark, and allow to stand for at least half an hour before being used. (See that the burette stopreocks unork smonthly and are not clogged with greuse.) ('oat the burette stopeocks with a very small amount of vaseline to prevent sticking. The cleaning mixture is to be used thronghout the course. Avoid the addition of water to the cleaning mixture. A burette is clean when the drops of water will not arlhere to the sides. Other useful cleaning mixtures are soap solutions, alcoholic KOH solutions, and ammoniacal alcohol solutions.

\section{Chemistry}

$$
\begin{aligned}
& \mathrm{K}_{2} \mathrm{Cr}_{2} \mathrm{O}_{7}+2 \mathrm{H}_{2} \mathrm{SO}_{4}=2 \mathrm{KHSO}_{4}+\mathrm{H}_{2} \mathrm{Cr}_{2} \mathrm{O}_{7} \cdot \\
& \mathrm{H}_{2} \mathrm{Cr}_{2} \mathrm{O} \text { breaks up into } \mathrm{H}_{2} \mathrm{CrO}_{4}+\mathrm{CrO}_{3} \text { (red ppt.). } \\
& 2 \mathrm{H}_{2} \mathrm{CrO}_{4}=\mathrm{Cr}_{2} \mathrm{O}_{3}+2 \mathrm{H}_{2} \mathrm{O}+3 \mathrm{O} . \\
& 2 \mathrm{CrO}_{3}=\mathrm{Cr}_{2} \mathrm{O}_{3}+3(\text { ). }
\end{aligned}
$$

Both $\mathrm{H}_{2} \mathrm{CrO}_{4}$ and $\mathrm{CrO}_{3}$ oxidize organic matter.

$$
\left(\mathrm{rr}_{2}()_{3}+3 \mathrm{H}_{2} \mathrm{SO}\right)_{4}=\left(\mathrm{rr}_{2}(\mathrm{SO})_{4}\right)_{3}+3 \mathrm{II}_{2} \mathrm{O} \text {. }
$$





\section{Questions}

1. Why does cleaning mixture clean? 2. Write equation. 3. What would you use to clean grease from glassware? Give reason. 4. After using the mixture for some time, it may become green in color. Give reason. 5. What is meant by the terms commercial and $C$. P. chemicals?

\section{Experiment No. 2}

PREPARATION OF AN APPROXIMATE N/10 NaOII SOLUTION

A normal solution is one which contains the hydrogen equivalent of the actire constituent in grams per liter; that is, the amount in a liter which brings into reaction $1.008 \mathrm{~g}$. of hydrogen or $8 \mathrm{~g}$. of oxygen, or their equivalent.

One molecule of $\mathrm{NaOH}$ bring's into reaction one atom of hydrogen when it reacts with an acicl. Therefore 40.0.5 $8 \mathrm{~g}$. of $\mathrm{NaOII}$ is equivalent to $1.00 \mathrm{~g}$. of hydrogen ; hence there are $40.058 \mathrm{~g}$. of $\mathrm{NaOII}$ in one liter of normal $\mathrm{NaOH}$ solution, and $4.0058 \mathrm{~g}$. in one liter of a $\mathrm{N} / 10$ NaOH solution.

Since the NaOII "sticks" contain about 10 to 20 per cent of water, weigh out (on rough balance) $5 \mathrm{~g}$., dissolve in distilled water, and dilute to one liter. Shake the solution thoroughly.

\section{Experiment No. 3}

\section{PREPARATION OF AN APPROXIIATE N/5 HCl SOLUTION}

One molecule of hydrochloric acid $(\mathrm{HCl})$ contains one replaceable liydrogen atom; therefore $36.458 \mathrm{~g}$. of hydrogen chloride furnishes $1.008 \mathrm{~g}$. of reacting hychrogen. In other words, the molecular weight of $\mathrm{HCl}(36.458)$ contains 

1.008 parts of reacting or replaceable hydrogen. Therefore it requires $36.4 \tilde{8} \mathrm{~g}$. of hydrogen chloride ( $\mathrm{HCl}$ ) for one liter of a normal hydrochloric acid (IICl) solution, and $7.2916 \mathrm{~g}$. for one liter of a $\mathrm{N} / 5$ hydrochlorie acid ( $\mathrm{HCl}$ ) solution.

The specific gravity of the C. P. concentrated hydrochloric acid solution on the reagent shelf should be determined by means of a specific-gravity spindle or hydrometer.

Example. Should the specific gravity of the C. P. concentrated hydrochloric acid solution on the reagent shelf be 1.175 , it would contain 34.43 per cent of hydrogen chloride by weight (see table of specific gravities, p. 85). 'Therefore 1.175 times $.3443=$ grams of hydrogen chloride in $1 \mathrm{cc}$. of the C. P. concentrated hydrochloric acid solution, and $\frac{7.2916}{1.175 \times .3443}=1$ s ec. of $C$. P'. concentrated hydrochloric acid required to furnish approximately $7.2916 \mathrm{~g}$. of hydrogen chloride. This is the weight or amount of hydrogen chloride recpuires for one liter of a $\mathrm{X} / \mathrm{j}$ hyedrochloric acid solution, providing the concentrated acid is of the above specific gravity.

Measure out the amount of the concentrated C. P. hydrochloric acid recquired hy your calculations (in the above example it would be 18 (ce) and clilute to one liter with distilled water. Shalie the solution thoroughly before using.

\section{Experiment No. 4}

\section{DETERMINATION OF EQUIVALENT VOLUMES}

Rinse out two burettes (which have been standing in cleaning mixture) with distilled water. After each burette is rinsed with distilled water, it should be rinsed again with a 5 ce. portion of the solution to be used in the respective burette, so as to remove any adhering particles

$$
\text { [4] }
$$



of water (letting the solution rum through the tip each time). Label the burette according to the solution to be used therein. Fill one of the burettes* a little above the zero mark with the approximate N/10 NaOH solution. Open the stopeock or pincheock cautiously until the reading of solution in the burette is zero. In the same manner fill the other burette with the approximate $\mathrm{N} / 5 \mathrm{HCl}$ solution, using the same care as to washing, ete. Draw out approximately $10 \mathrm{ce}$. of the $\mathrm{NaOH}$ solution into a $250 \mathrm{cc}$. Erlemmeyer flask or beaker. I)ilute to 50 ce. with clistilled water, ard one drop of methyl orange, and then rapidly add the IICl solution until the solution in the flask or beaker changes color, indicating an acid solution. Now bring the flask or beaker unler the burette containing the NaOII, and add the Na()II solution more slowly, until the color turns yellow. Then bring the flask or beaker under the burette containing the IIC:1, and arde the IICl solution slowly until the solution turns red. Continue this operation until a point is obtainerl where one drop, or even half a drop, of either solution will cause a color change. When this point - known as the end-point - is reached, allow the solutions in the burettes to drain for a minute, and then rearl the exact volume of each solution used.

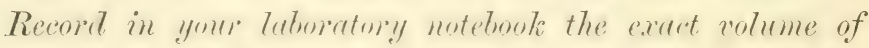
solution used. As a check on this determination and also as work with inclicators, make titrations, using phenolphthalein, cochineal, and methyl red as indicators. Make at least two titrations with each inclicator. Different determinations should agree within $.05 \mathrm{cc}$. Take the average of the titration for the calculations. From the data

* It is advisable to use a rubber-tipped burette for the alkali solution. 

obtained calculate and report the cubic centimeters of $\mathrm{HCl}$ solution neutralized by $1 \mathrm{cc}$. of the $\mathrm{NaOH}$ solution. Also calculate and report the cubic centimeters of $\mathrm{NaOH}$ solution neutralized by $1 \mathrm{ce}$. of the $\mathrm{HCl}$ solution.

\section{Questions}

1. How many grams of the following reagents will be required for one liter of a normal solution; one liter of fifth-normal solution: $\mathrm{HNO}_{3}, \mathrm{H}_{2}, \mathrm{O}_{4}, \mathrm{H}_{3} \mathrm{PO}_{4}, \mathrm{H}_{2}\left(\mathrm{c}_{2} \mathrm{O}_{4}, 2 \mathrm{H}_{2} \mathrm{O}\right.$, $\mathrm{NH}_{4}\left(\mathrm{HI}, \mathrm{NaII}()_{3}, \Lambda_{9} \mathrm{NO}_{3}, \mathrm{~K}_{2} \mathrm{~S}()_{4}\right.$ ? 2. How many culbie centimeters (ce.) of $\mathrm{N} / 10 \mathrm{HCl}=15 \mathrm{cc}$. of $\mathrm{N} / 1 \mathrm{NH}_{4} \mathrm{OH} ? \mathrm{~N} / 5$ $\mathrm{K}_{2}\left(\mathrm{C}_{3} ? \mathrm{~N} / 10 \mathrm{NaO}\right) \mathrm{II} ! \mathrm{N} / 1 \mathrm{KOH}=10\left(\cdots ? \mathrm{~N} / 4 \mathrm{H}_{2}\left({ }_{2} \mathrm{O}_{4} ? \mathrm{~N} / 2\right.\right.$ $\mathrm{H}_{2} \mathrm{SO}_{4}$ ? 3. If $8 \mathrm{~g}$. of a sample containing some $\mathrm{XaO}$ (II were dissolved in 200 ('e. of distilled water, and 20 ('e of this solution were equivalent to 15 ce. of a $\mathrm{N} / 5$ acid, what would be the percentage of $\mathrm{NaOH}$ in the original material?

\section{Experiment No. 5}

\section{PREPARATION OF A PERFURATED OR GOOCII CRUCIBLE}

Prepare two crucibles in the following manner: Place the Gooch fumnel in the neck of a filter flask by means of the rubber stopper, stretch the rubber band over the funnel, and place the crucible in the opening. Connect the filter flask, by means of a rubber tubing, to the filter pump, and before turning on the suction pour into the crucible some of the coarse, suspended asbestos* (obtained by shaking the bottle). When the water has filtered through, turn on the suction and pour on some of the finer asbestos (supernatant liquicl obtained on allowing the solution to settle a short time). Tap well with flattened glass rod, and add another layer. Then wash

* Prepared according to directions on page 88 . 

with at least 100 (e. of clistillexl watter, and dry in the air bath at $1: 30^{\circ}-1500^{\circ}$ ( . for two homers. Cool in desieretor, and weigh acculately to tentls of a milligram. (Crucibles

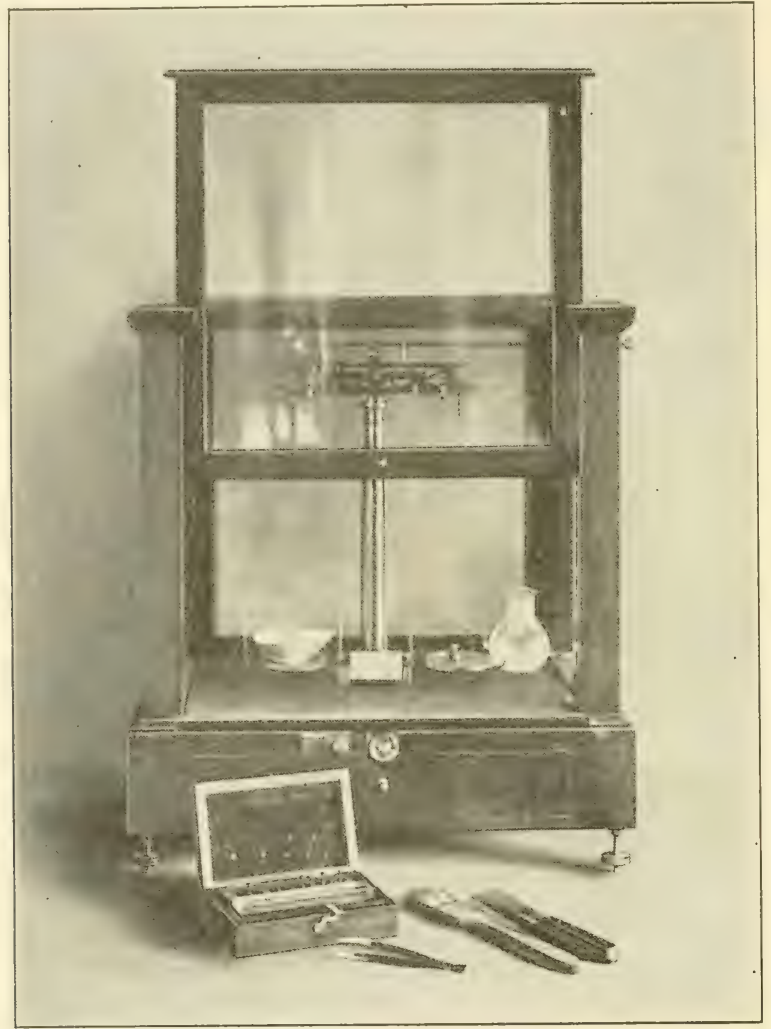

ANALY'TICAL BALANCE

should be hamdlext only with cleam forceps.) The asbestos filn should be thin enough to be translucent when wet, but not so thin that it will be liable to permit a fine precipitate to pass through. 

Do not put any labels on the crucibles, and do not mark them. They may be identified by placing them in a labeled fumnel.** The crucibles should be treated in the same way before and after receiving the precipitates. This applies to the length of time in the drying oven, the heat applied, and the length of time they stand in the desiccator before weighing.

\section{Questions}

1. What is asbestos, and how is it obtained? 2. How should asbestos be prepared for use in a Gooch crucible? 3. In Experiment No. 5, why not filter through a filter paper? 4. Give three precautions that should be taken when using a desiccator. 5. Name four reagents that could be used in a desiccator, for drying purposes, and discuss their efficiency.

\section{STANDARDIZATION OF IICI SOLL"TION BY GRAVIMETRIC METHOD}

Into two $250 \mathrm{cc}$. Erlenmeyer flasks, which have been cleaned with cleaning mixture and carefully rinsed with distilled water, measure out accurately from a burette 25 cc. portions of IICl solution. (Allow the burette to drain for about five minutes before reading.) Add 75 ce. of distilled water, 5 c.c. of C. P. cencentrated $\mathrm{HNO}_{3}$ solution, and then a solution of silver nitrate ${ }^{\dagger}\left(\mathrm{AgNO}_{3}\right)$ very gradually and with constant agitation of solution until the precipitation is complete. Close the flask with a clean rubber stopper, wrap in a black cloth, and shake the flask vigorously for several minutes until the $\mathrm{AgCl}$

* Crucibles may be permanently marker for identification either with China paints by Yoder's method (circular of Bureau of Chemistry) or, more conveniently, by burning in a "grease" Prussian blue pencil mark. J. E. Huber, Chemist Analyst, January, 1915, p. 25.

+ Prepared according to directions on page 89. 

is flocculated and the supernatant liquid is perfectly clear. When the precipitation is complete, the supernatant liquid quickly becomes clear. To this clear portion a drop of silver nitrate may be added to decide whether enough has been added for complete precipitation of the hydrochloric acid. Avoid the addition of an excess of the silver solution. It is necessary to protect the flask containing the precipitate from the light, as much as possible, as light tends to decompose the silver chloride precipitate $(\mathrm{AgCl})$.

Let the precipitate settle, then filter off the supernatant liquid through the tared Gooch crucible by suction, introducing as little of the precipitate as possible on the filter. Wash with about $150 \mathrm{cc}$. of a cold 1 per cent $\mathrm{INO}_{3}$ solution by similar decantation through the Gooch. Transfer the precipitate, without loss, from the flask to the tared crucible, with about $100 \mathrm{ce}$. more of a 1 per cent $\mathrm{IINO}_{3}$ solution, making sure that none is left in the flask or on the rubber stopper, and wash thoroughly with a 1 per cent $\mathrm{HNO}_{3}$ solution until 15) ce. of the filtrate does not give a test for silver nitrate $\left(\mathrm{Ag} \mathrm{NO}_{3}\right)$. Suck fairly dry. Dry the crucible and contents for two hours at $130^{\circ}-150^{\circ} \mathrm{C}$., cool in desiccator, and weigh. Ileat again for one hour, cool, and reweigh. Repeat until weight is constant. Duplicates must not differ in weight more than $1 \mathrm{mg}$. At least four trials should be made.

\section{Chemistry}

$$
\mathrm{AgNO}_{3}+\mathrm{HCl}=\mathrm{AgCl}+\mathrm{HNO}_{3}
$$

Mol. wt. of $\mathrm{AgCl}$ : mol. wt. of $\mathrm{HCl}:$ : weight of ppt. : $x$ $x=$ grams of hydrogen chloride (IICl) in number of cubic centimeters of hydrochloric acid solution used. 

$\frac{x}{\text { Volume of } \mathrm{HCl} \text { used }}=$ grams of hydrogen chloride (HCl) in 1 ce. of the hydrochloric acid solution, which is known as the titre of that solution.

\section{Questions}

1. Show how to make a $\mathrm{N} / 10 \mathrm{HC}$ 'l solution, a $\mathrm{N} / 5 \mathrm{H}_{2} \mathrm{SO}_{4}$ solution, a $\mathrm{N} / 10 \mathrm{HNO}_{3}$ solution, a $\mathrm{N} / 20 \mathrm{NaOH}$ solution, using $\mathrm{HCl}$, sp. gr. $1.185 ; \mathrm{H}_{2} \mathrm{SO}_{4}$, sp. gr. $1.8 ; \mathrm{HNO}_{3}$, sp. gr. 1.4; $\mathrm{NaOH}$, containing 20 per cent of water. 2. What is the percentage of $\mathrm{Ag}$ in $\mathrm{Ag}(\mathrm{C})$ ? Fe in Fes( ${ }_{4}\left(\mathrm{NII}_{4}\right)_{2} \mathrm{SO}_{4} \cdot 6 \mathrm{H}_{2}(\mathrm{O})$ ? $\mathrm{S}$ in $\mathrm{BaSO}_{4}$ ? and (aO in (a) (') $)_{3}$ ? 3. How many cubie centimeters of $\mathrm{HCl}$ (s1) gr. 1.2) are necessary to precipitate completely the silver in $2 \mathrm{~g}$. of $\mathrm{AgNO}_{3}$ ? 4. How many cubic centimeters of $\mathrm{N} / 10 \mathrm{AgNO}$ solution will be necessary to precipitate the chlorine from $12 \mathrm{~g}$. of $\mathrm{CaCl}_{2}$ ? 5 . What effect has light upon $\mathrm{AgCl}$ ? Explain.

\section{Experiment No. 6}

I. STANDARDIZATION ()E THE HC' SOLUTION BY VOLUMETRIC METHOD

Weigh ont accurately 0.2 to $0.3 \mathrm{~g}$. portions of C. P. $\mathrm{Na}_{2} \mathrm{CO}_{3}$ into $250 \mathrm{ce}$. Erlenmeyer flasks or beakers, and dissolve each portion in $50 \mathrm{cc}$. of distilled water. Add one drop of methyl orange to one portion, and titrate with $\mathrm{HCl}$ solution until the first tinge of pink appears. Repeat the operation with the second portion. Record accurately the burette readings.

\section{Chemistry and Calculations}

$$
\mathrm{Na}_{2} \mathrm{CO}_{3}+2 \mathrm{HCl}=2 \mathrm{NaCl}+\mathrm{H}_{2} \mathrm{O}+\mathrm{CO}_{2}
$$

Mol. wt. of $\mathrm{Na}_{2} \mathrm{CO}_{3}:$ mol. wt. of $2 \mathrm{HCl}:$ : wt. of $\mathrm{Na}_{2} \mathrm{CO}_{3}: x$ 106.1 : 72.916: : weight of $\mathrm{Na}_{2} \mathrm{CO}_{3}$ taken : $x$

$$
\text { [10] }
$$



$\frac{x}{\text { Volume of } \mathrm{HCl} \text { used }}=$ grams of hydrogen chloride (IICl) in $1 \mathrm{cc}$. of the hydrochloric acid solution, which is known as the titre of that solution. If the duplicates

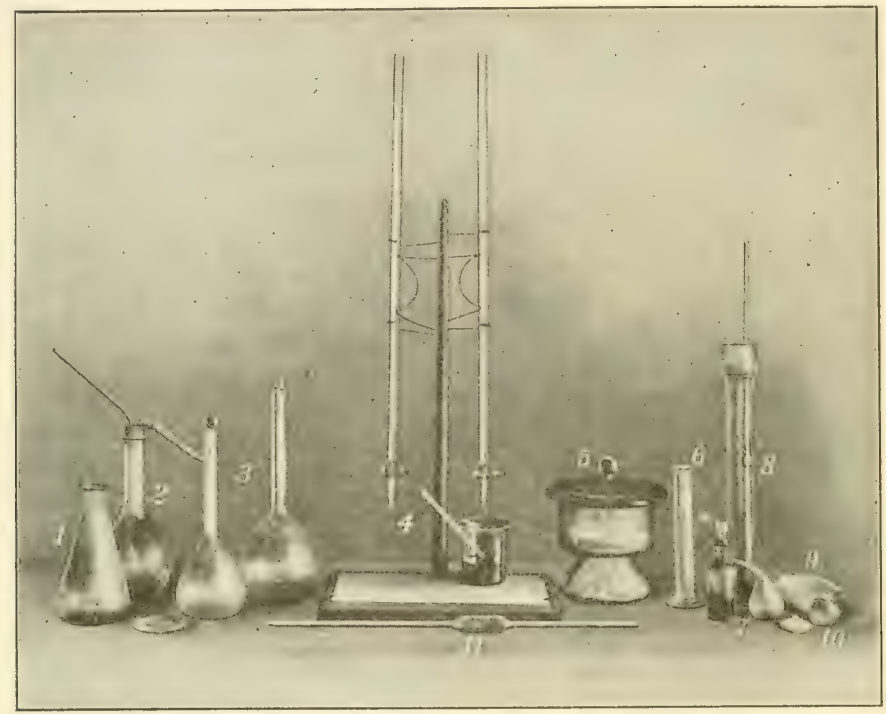

APPARATUS FOR QUANTITATIVE ANALYSIS

1, Erlenmeyer flask (500 cс.) ; 2, wash bottle ; 3, measuring flasks (500 and 1000 cc.) ; 4, burettes and burette holder; 5 , desiccator; 6, gradnated cylinder $(50 \mathrm{ce}$ ) ; $\tilde{z}$, indicator bottles; $\delta$, specific-gravity hydrometer and cylinder; 9, porcelain evaporating dish; 10, porcelain crucible and cover; 11 , pipette (25 cc.)

do not agree to within $0.0 .5 \mathrm{mg}$, the work must be repeated until the duplicates do agree. The results of this experiment should check with those obtained in Experiment No. 5. Report the titre of the HCl solution as obtained in the two experiments. 

11. CALCULATION OF THE TITRE OF TIE NaOH SOLUTION

By the use of the titre of the hydrochloric acid solution determined in Experiment No. 5 and the volume of hydrochloric acid solution neutralized by 1 cc. of the $\mathrm{NaOH}$ solution, as determined from the equivalent volume work (Exp. No. 4), calculate the titre of the NaOH solution.

\section{Chemistry}

$$
\mathrm{NaOH}+\mathrm{HCl}=\mathrm{NaCl}+\mathrm{H}_{2} \mathrm{O}
$$

$40.008: 36.458:: x:$ (titre of $\mathrm{HCl}$ solution) times (the cubic centimeters of $\mathrm{HCl}$ neutralized by 1 ce. of the $\mathrm{NaOH})$.

$x=$ grams of $\mathrm{NaOH}$ in 1 ce. of the $\mathrm{NaOH}$ solution, which is known as the titre of that solution.

\section{Questions}

1. Define a normal solution, a standard solution, and a per cent solution. 2. Give difference between N/1 HCl and 1 per cent $\mathrm{HCl}$ solution. 3. Give the titre of the following solutions: 1.25 per (x) $\mathrm{Na}\left(1 \mathrm{H} ; 1.25\right.$ per (ent $\mathrm{H}_{2} \mathrm{~s}()_{4} ; 4$ per cent $\mathrm{NH}_{4} \mathrm{OH}$. 4. What is the difference, if any, between a 5 per cent $\mathrm{NaOH}$ and a $\mathrm{N} / 5 \mathrm{NaOH}$ solution?

\section{Experiment No. 7}

DETERIINATION OF THE STRENGTII OF AN LNKNOWN ALKALI SOLUTION

After cleaning a burette and rinsing with a is ce. portion of the unknown solution, fili it to the zero mark, accorcling to directions in Experiment No. t. In the same manner fill the other burette with the $\mathrm{N} / \tilde{j}$ IICl solution. Titrate the one solution against the other, using methyl orange as an indicator and the same volumes as in the 

equivalent volume work ( $10 \mathrm{cc}$. of the solution diluted to $\tilde{50}$ cc., etc.). Run duplicate determinations. Calculate and report grams of $\mathrm{NaOII}$ per cubic centimeter of the unknown solution.

\section{Experiment No. 8}

DETERMINATION OF THE STRENGTH OF AN UNKNOWN ACID SOLUTION

Perform as in preceding experiment, using your standard N/10 NaOII solution. Rum duplicate determinations. Calculate and report grams of $\mathrm{IICl}$ per cubic centimeter of the unknown solution.

\section{Experiment No. 9}

DETERMINATION OF THE STRENGTI OF AN UNKNOWN $\mathrm{K}_{2} \mathrm{CO}_{3}$ SOLUTION, CSING METHYL ORANGE AS INDICATOR

Measure ont, with burette, two $20 \mathrm{ce}$. portions of the unknown $\mathrm{K}_{2} \mathrm{CO}_{3}$ solution, dilute with $50 \mathrm{cc}$. of distilled water, and titrate in the same manner as with $\mathrm{Na}_{2} \mathrm{CO}_{3}$ in Experiment No. 6. Make at least two trials, and more if necessary to make titrations check. ('alculate and report the amount of $\mathrm{K}_{2} \mathrm{CO}_{3}$ and also its equivalent in $\mathrm{K}_{2} \mathrm{O}$ per cubic centimeter of the unknown solution.

$$
\mathrm{K}_{2} \mathrm{CO}_{3}+2 \mathrm{HCl}=2 \mathrm{KCl}+\mathrm{H}_{2} \mathrm{O}+\mathrm{CO}_{2}
$$

\section{Experiment No. 10}

DETERMINATION OF THE STRENGTH OF AN UNKNOWN $\mathrm{K}_{2} \mathrm{CO}_{3}$ SOLUTION, LSING PHENOLPHTIALEIN AS INDICATOR

Measure out, with burette, two $20 \mathrm{cc}$. portions of the unknown $\mathrm{K}_{2} \mathrm{CO}_{3}$ solution, dilute with $50 \mathrm{cc}$. of distilled water, and titrate in the same manner as in Experiment 
No. 9, using phenolphthalein as indicator. Calculate and report the amount of $\mathrm{K}_{2} \mathrm{CO}_{3}$ and its equivalent in $\mathrm{K}_{2} \mathrm{O}$ per cubic centimeter of the unknown solution. The phenolphthalein inclicates only half the carbonates, as indicated by the equation

$$
\mathrm{K}_{2} \mathrm{CO}_{3}+\mathrm{HCl}=\mathrm{KHCO}_{3}+\mathrm{KCl}
$$

\section{Experiment No. 11}

DETERMINATION OF TIIE STRENGTII OF AN UXKNOWN $\mathrm{NaOH}$ AND $\mathrm{Na}_{2} \mathrm{CO}_{3}$ SOLUTION

In the preceding experiments it was shown that the hydroxides of sodium and potassium arted differently from the carbonates toward some indieators and that the (arbonates areterl differently with different indicater's. When phenolphthalein is used as indicator, all the metal of the hydroxicle is neutralized, while only half is neutralized in the carbonate. When methyl orange is med as indicator, all the metal of hydroxide and carbonate is neutralized. It ought, therefore, to be possible to tell the amount of a carbonate in a solution of a hychroxicle by making titrations, using methyl orange and phenolphthalein as indicators.

Measure out, with burette, 10 c.c. of the mknown solution; dilute with 50 ('e. of distilled water; and titrate, using phenolphthalein as inclicator, ${ }^{*}$ noting the cubic centimeters of acid required. Measure out another portion of 10 ce., and titrate, using methyl orange as indicator. 'The phenolphthalein shows all the hydroxide and half the carbonate; the methyl orange show's all the hydroxide and all the carbonates. From data obtained calculate and report

* Prepared according to directions on page 88.

$$
\text { [14] }
$$



the amounts of carbonate and liydroxide per cubic centimeter of the unknown solution. Write all equations illustrating the reaction and give methods of calculating results.

\section{Question}

Discuss the use of indicators.

\section{References}

Corr. Indicators and Test Papers.

Monse. Exercises in Quantitative Analysis, pp. 110-115.

Noyes, W. A. A Textbook of Chemistry, pp. 387-390.

Stieglitz. Journal of American Chemical Society, Vol. XXV, p. 1114.

Sutton. Volumetric Analysis.

Tizard. Indicators.

Treadwell-Ilall. Analytical Chemistry, Vol. II, Pl. 426-435.

\section{Experiment No. 12}

DETERMJNATION OF ACETIC ACID IN VINEGAR

The formula of acetic acid is $\mathrm{IIC}_{2} \mathrm{I}_{3} \mathrm{O}_{2}$. It has one replaceable hydrogen atom. Take 5 ce. of vinegar, measured by means of a burette or pipette, dilute to 100 cc. with distilled water, and titrate with your standard N/10 NaOII solution. Run duplicates. Use phenolphthalein as the indicator in the titration. Calculate and report grams of acetic acid in $1 \mathrm{cc}$. of the vinegar.

\section{Questions}

1. Considering that $1 \mathrm{cc}$. of vinegar weighs $1 \mathrm{~g}$., what is the per cent of acetic acid in the sample of vinegar examined? 2. What is the standard in your state and in the United States for pure vinegar as to acidity and total solids?

\section{Reference}

Leacu. Food Inspection and Analysis (3d ed.), p. 772. 1914.

$$
\text { [15] }
$$




\section{Experiment No. 13}

DETERMINATION OF TOTAL SOLIDS IN VINEGAR

Weigh a small porcelain evaporating dish which has been previously cleaned and dried. Measure ont exactly, with a burette, 10 ce. of the sample of rinegrar to be analyzed, and evaporate this to dryness on a water bath; then dry for three hours in a water oren (or drying oven) at the temperature of boiling water. ('ool the dish and solids in desiecator, and weigh. From the figures obtained ("alculate and report the percentage of total solicls in the sample. Make two determinations.

\section{Question}

What is indieaterl lyy a low total-solids content?' Discuss.

\section{Experiment No. 14}

\section{DETERMINATION OF ASH IN VINEGAR}

Take the solid residues from the previous experiment and ignite over a low flame until you obtain a grayishwhite ash. Cool the dish and ash in desiceator, and weigh. The weight obtained minus the weight of the dish represents the weight of the ash in the amount of vinegar used. From the results olotained calculate and report the percentage of ash in the sample. Make two determinations. Test for water-soluble phosphates. Also test for phosphates insoluble in water but soluble in dilute hydrochloric acid.

An Argand burner with mica chimney or an electric muffle furnace may be successfully used for ashing. The 

flame is kept low until charring is complete, then turned as high as it can be raised without smoking.

\section{Questions}

1. Explain the relationship of phosphates to the purity of vinegar. 2. Give a quick method for the manufacture of vinegar. 3. Explain the conditions necessary for the making and keeping of apple vinegar. 4. Compare the composition of eider with that of cider vinegar.

\section{Reference}

LEAcr. Food Inspection and Analysis (3d ed.), 11. 759-782. 1914.

\section{Experiment No. 15}

PREPARATION OF STANDARD POTASSILM PERIAATGANATE SOLUTION $\left(\mathrm{KMnO}_{4}\right)$

Dissolve $3.2 \tilde{\mathrm{g}} \mathrm{g}$. of $\mathrm{KMnO}_{4}$ in 1 liter of distilled water. Let the solution stand until the next laboratory period, and then filter through a properly prepared perforated or Gooch crucible (prepared as in Exp. No. 5, Part I). Standardize the $\mathrm{KMnO}_{4}$ solution against a known solution of ferrous ammonium sulphate $\left(\mathrm{FeSO}_{4} \cdot\left(\mathrm{NII}_{4}\right)_{2} \mathrm{SO}_{4} \cdot 6 \mathrm{H}_{2} \mathrm{O}\right)$ as follows:

Place $3.5 \mathrm{~g}$. (exactly weighed) of C. P. ferrous ammonium sulphate in a 200 or $250 \mathrm{cc}$. measuring flask, and make up to the mark with distilled water. Shake until the salt is completely dissolved. By means of a pipette or burette measure out $50 \mathrm{cc}$. of the ferrous ammonium sulphate solution into a beaker, add $25 \mathrm{cc}$. of sulphuric acid $\left(\mathrm{II}_{2} \mathrm{SO}_{4}\right)$ strength $1: 4$, and dilute to about $100 \mathrm{cc}$. with distilled water. Add the KMnO, solution from a burette until one drop gives a permanent pink color. At least three titrations should be made. From the data obtained and 

the following equation calculate the amount of iron (Fe) oxidized by $1 \mathrm{ce}$. of the $\mathrm{KMnO}_{4}$ solution.

$$
\begin{aligned}
& \left.\mathrm{FeSO}_{4}\right) \\
& \left.\left(\mathrm{NH}_{4}\right)_{2} \mathrm{SO}_{4}\right\}+\mathrm{K} . \mathrm{InO}_{4}+\mathrm{II}_{2} \mathrm{SO}_{4}=\mathrm{Fe}_{2}\left(\mathrm{SO}_{4}\right)_{3}+\mathrm{K}_{2} \mathrm{SO}_{4}+\mathrm{MnSO}_{4} \\
& 6 \mathrm{H}_{2} \mathrm{O}+\left(\mathrm{NH}_{4}\right)_{2} \mathrm{SO}_{4}+\mathrm{H}_{2} \mathrm{O}
\end{aligned}
$$

(Balance the equation.)

Observe that one seventh of the weight of the ferrous ammonium sulphate is iron ( $\mathrm{Fe}$ ).

\section{Questions}

1. Show that one serenth of the weight of ferrous ammonium sulphate is iron. 2. How many grams of $\mathrm{K}^{2} \mathrm{InO}_{4}$ would be recguired for a $\mathrm{X} / 10 \mathrm{~K} .1 \mathrm{nO} \mathrm{O}_{4}$ solution? How many grams of $\mathrm{K}_{2}\left(\mathrm{C}_{2} \mathrm{O}_{7}\right.$ would be recpuired for a $\mathrm{N} / 10 \mathrm{~K}_{2}\left(\mathrm{C}_{2} \mathrm{O}_{7}\right.$ solution? 3. Problem: weight of iron ore taken is $.2 \mathrm{~g}$.; volume of $\mathrm{N} / 10 \mathrm{~K} \mathrm{~K}_{2} \mathrm{O}_{7}$ recpuired for titration is $20 \mathrm{ce}$. What is the percentage of $\mathrm{Fe}$ in the sample?

\section{Experiment No. 16}

DETERMINATION (OF TILE AMOLNT OF CALCILA OXIDE IN LIMESTONE

The sample of lime, limestone, or material containing calcium ground to a fine powder is thoroughly mixed, and approximately $2 \mathrm{~g}$. of the mixture (exactly weigher) is placed in a beaker with $25 \mathrm{cc}$. of concentrated liychrochloric acid ( $\mathrm{HCl}$ ) and 2:5) ( $\%$ of distilled water. If necessary, the solution is leated to get the calcium compounds in solution. Possibly all the material does not go into solution, as the material may contain some silica $\left(\mathrm{SiO}_{2}\right)$. The calcium salts are with a little heating readily dissolved in the dilute acil. After the material is in solution, the solution in the beaker is transferred by filtering into 

a 200 or 250 cc. measuring flask. Distilled water is used to wash out the beaker and to wash any material in the filter free of any soluble substance. The solution in the measuring flask is then made up to the mark with distilled water, shaken until thoroughly mixed, and two portions of $25 \mathrm{cc}$. each are measured out by means of a pipette or burette and placed in two beakers. To each of the portions $25 \mathrm{cc}$. of distilled water is added, then ammonium hydroxide ( $\mathrm{NI}_{4} \mathrm{OH}$ ) solution is added until alkaline. The solution is heated to boiling, and while boiling a solution of ammonium oxalate $\left(\left(\mathrm{NH}_{4}\right)_{2} \mathrm{C}_{2} \mathrm{O}_{4}\right)$ is added dropwise until the calcium is completely precipitated as calcium oxalate. The complete precipitation of the calcium is determined by allowing the precipitate to settle, and adding a drop of the ammonium oxalate solution to the supernatant liquid. If the precipitation is not complete, a precipitate will be formed; in which case the solution is to be treated again as at first.

Allow the precipitate to settle, filter while hot, and wash free from soluble oxalates, using hot water. The precipitate in the beaker should be thoroughly washed free of soluble oxalates, but it does not need to be completely transferred to the filter paper, as the filter paper and precipitates are later to be returned to the same beaker in which the precipitation took place. After the precipitate in the beaker and in the filter paper is thoroughly washed, return the filter paper and precipitate to the beaker from which it was filtered, add about $50 \mathrm{cc}$. of water and $10 \mathrm{cc}$. of sulphuric acid $(1: 1)$, heat nearly to boiling, and titrate with the standard $\mathrm{K}^{r} \mathrm{InO}_{4}$ solution until you get a permanent pink color.

* Prepared according to directions on page 89. 


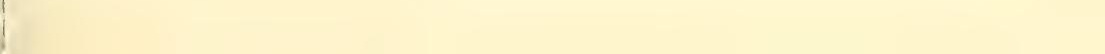


Precaution. Do not heat the solution to boiling, but bring it nearly to boiling. Explain. Save standard $\mathrm{KMnO}_{4}$ solution for other experiments.

\section{Calculation of Results}

Write all equations for the solution of the calcium compound and its precipitation. The reaction with $\mathrm{KMnO}_{4}$ gives the following equation:

$$
\begin{aligned}
\mathrm{CaC}_{2} \mathrm{O}_{4}+\mathrm{H}_{2} \mathrm{SO}_{4}+\mathrm{KMnO}_{4} & \mathrm{KaSO}_{4}+\mathrm{MnSO}_{4}+\mathrm{K}_{2} \mathrm{SO}_{4}+\mathrm{CO}_{2}+\mathrm{H}_{2} \mathrm{O} \\
& \text { (Balance the equation.) }
\end{aligned}
$$

By comparing the equations for oxidation of $\mathrm{Fe}$ and $\mathrm{CaC}_{2} \mathrm{O}_{4}$, it will be seen that the same amount of $\mathrm{KMnO}_{4}$ oxidizes twice as much of the iron compound as of the calcium oxalate. As the molecular weight of $\mathrm{CaO}$ and the atomic weight of $\mathrm{Fe}$ are about the same, the factor for iron divided by 2 gives the factor for $\mathrm{CaO}$; or the titre of $\mathrm{KMnO}_{4}$ in terms of $\mathrm{Fe}$ divided by 2 gives the titre of $\mathrm{KMnO}_{4}$ in terms of $\mathrm{CaO}$. Calculate and report from the results the percentage of $\mathrm{CaO}$ in the sample.

\section{Questions}

1. If you had a sample of pure limestone, what per cent of $\mathrm{CaO}$ should you obtain by its analysis? 2. How many pounds of $\mathrm{CaO}$ and $\mathrm{Ca}(\mathrm{OH})_{2}$, are equivalent to $100 \mathrm{lb}$. of air slaked lime? 3. One cubic centimeter of $\mathrm{N} / 10 \mathrm{~K} M \mathrm{InO}_{4}$ solution will oxidize $.0056 \mathrm{~g}$. of iron ( $\mathrm{Fe}$ ). If $.2 \mathrm{~g}$. of a sample of barium oxalate requires 10 ce. of the $\mathrm{KMnO}_{4}$ solution, what is the percentage of barium oxalate in the sample? 


\section{PART II}

\section{ANALYSIS OF FEEDSTUFFS}

\section{Preparation of a Saiple of Feedstuff for Analysis}

The sample of feedstuff should be prepared for analysis by grinding the material to pass through a sieve having circular perforations $1 \mathrm{~mm}$. in diameter. After sample is prepared and thoroughly mixed, it should be kept in a well-stoppered bottle. Enough of the sample should be prepared for the complete analysis.

\section{Experiment No. 17}

DETERMINATION OF MOISTURE IN FEEDSTUFFS

Weigh out exactly $2 \mathrm{~g}$. of the feed sample in a weighed watch glass, and dry for three hours in a water oven at the temperature of boiling water; cool in desiccator, and weigh rapidly. Heat again, and weigh at intervals of one-half hour until the material ceases to lose weight. Make duplicate determinations. Calculate and report the percentage of moisture in the sample.

\section{Question}

Why heat at the temperature of boiling water, as specified, instead of at the temperature of $100^{\circ} \mathrm{C}$. ?

\section{[21 ]}




\section{Experiment No. 18}

\section{DETERMINATION OF ASH IN FEEDSTUFFS}

The residue from Experiment No. 17, or a weighed amount (from 2 to $3 \mathrm{~g}$.) of the original material, is ignited gently over a small flame in a weighed porcelain crucible to

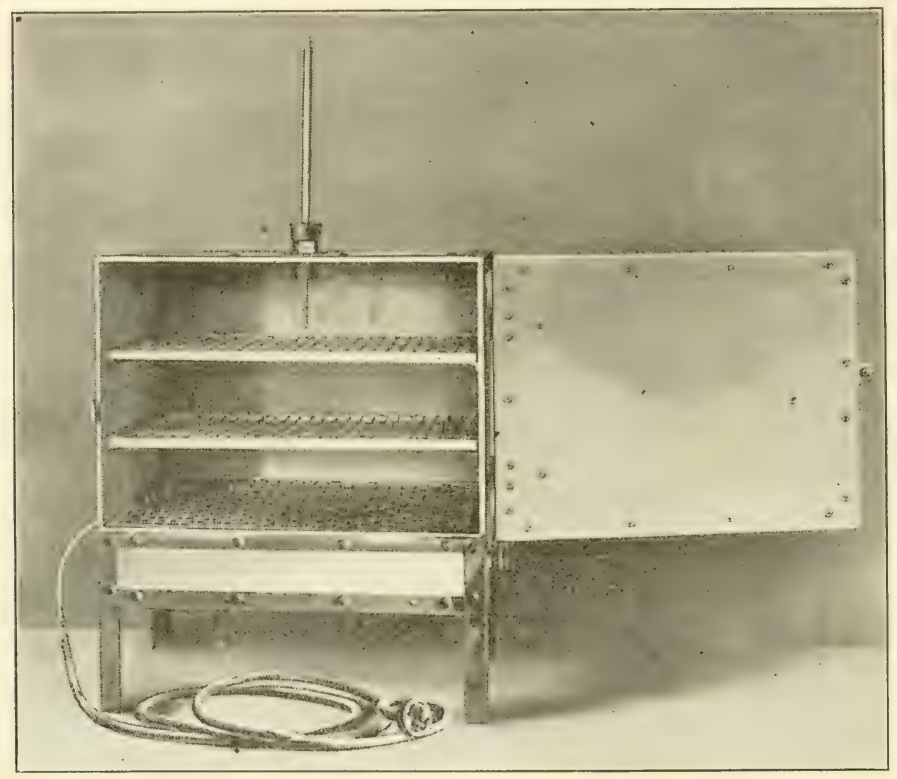

ELECTRIC DRYLNG OVEN

An accurate, inexpensive, and convenient type

a constant weight. Be sure to weigh the crucible before placing the weigherl sample of feed in it. Make duplicate determinations. ('alculate and report the percentage

$$
\text { [22] }
$$


of ash in the sample examined. Make a qualitative analysis of plant ash for essential elements of plant food, and report results.

\section{Question}

What value has the ash determination in the analysis of feedstuff?

\section{Experiment No. 19}

\section{DETERMINATION OF CRUDE PROTEIN IN FEEDSTUFFS}

\section{Apparatus}

K jeldahl flasks of $800 \mathrm{ce}$. for both digestion and distillation, a safety bulb, and a condenser.

Weigh out accurately a convenient quantity of the feed sample (from 0.7 to $1.4 \mathrm{~g}$.) and transfer it to the $\mathrm{K}$ jeldahl flask. The neck of the flask should be dry, so that none of the material sticks on the neck. Add 25 cc. of concentrated C. $\mathrm{P} . \mathrm{H}_{2} \mathrm{SO}_{4}$ and approximately $0.3 \mathrm{~g}$. of $\mathrm{CuSO}_{4}$. Support the flask in a sloping position on a wire gauze or on a piece of asbestos board with a hole in the center. Heat gradually to boiling with a Bunsen flame (heating should be done in a hood or some arrangement made to remove the fumes so they will not get into the room).* As soon as the acid is boiling freely and any frothing has ceased, remove the flame; and when the contents have cooled, add about $5 \mathrm{~g}$. of C. $\mathrm{P} . \mathrm{K}_{2} \mathrm{SO}_{4}$. The heating is renewed and continued until the material is completely oxidized. This will be shown by the acid's becoming clear and having only a slight blue or green tint. After removing the flame a few small pieces of

* Fumes can be removed by means of an earthenware or lead fume duct or by means of a Sy fumeless digestion apparatus.

$$
\text { [23] }
$$



K.MnO may be added to make sure that the oxidation is complete. This should be aulded until it permanently color's the solution. 'The flask and contents are allowed to cool completely, then 200 to 250 c.c. of distilled water is arlect. Through a thistle tuhe which should reach to the bottom of the flask, or by slanting the flask and pouring down the side, there is now arterl about $75 \mathrm{cc}$. of

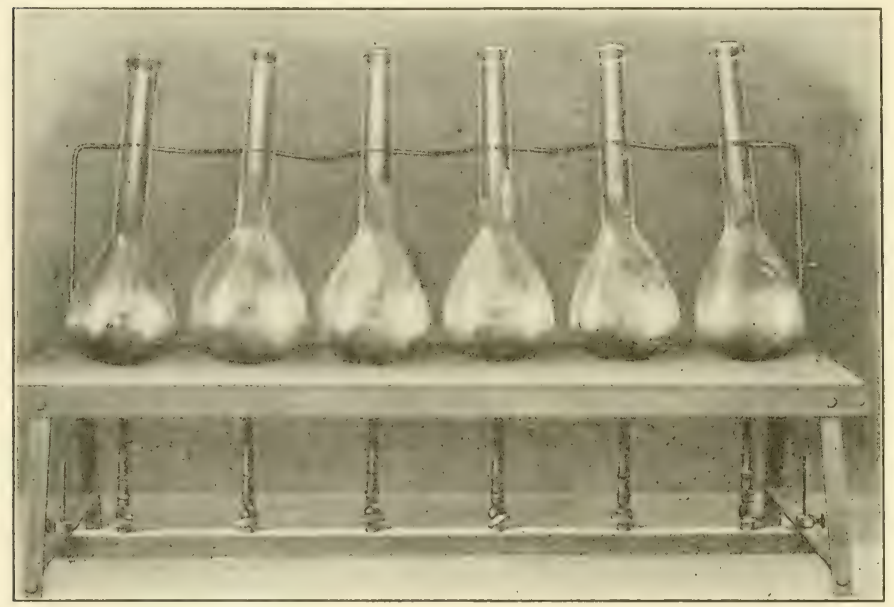

KJELDAHL DIGESTION APPARATUS

concentraterl NaOII solution * (free of carbonates). Do not shake the solution in the flask before it is connected with the safety bull, ancl distillation apparatus. 1 small piece of gramulated zine or a little zine dust is arded to prevent humping in the sulnserquent distillation. Insert the safety bulb in the flask and connect with a condenser. Grently shake the flask to mix its contents, and distill the ammonia into a measured amomut (25) (e.) of the standard * Prepared according to directions on page 89 . 

$\mathrm{N} / 5 \mathrm{HCl}$ solution (acid must be measured exactly from a burette). The receiver may conveniently be a $250 \mathrm{cc}$. Erlenmeyer flask. The end of the distillation tube should extend down into the standard $\mathrm{HCl}$ solution. When about $100 \mathrm{cc}$. have been clistilled over, making a volume of approximately $125 \mathrm{cc}$. in the flask, the distillation may be stopped.

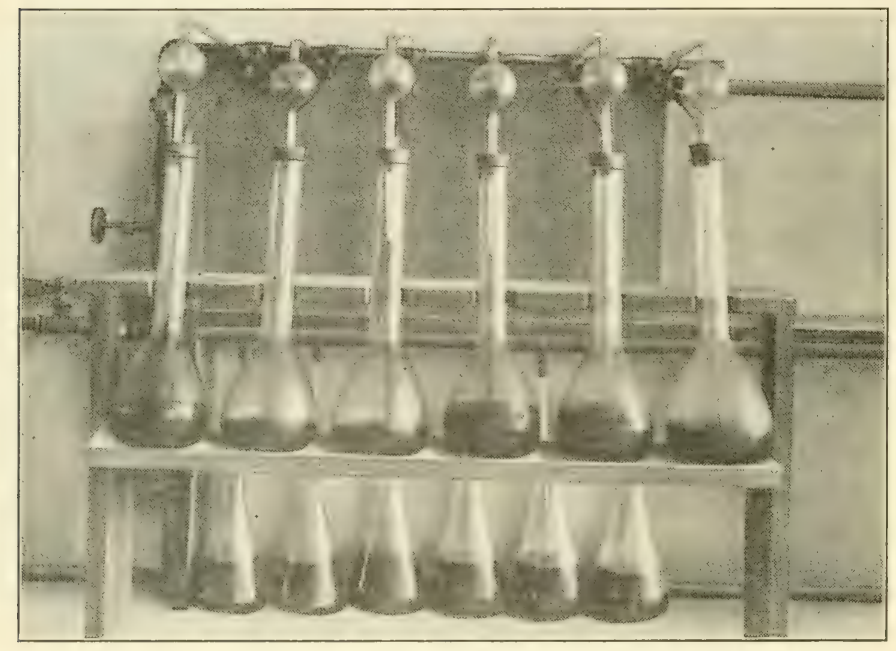

KJELDAHL DISTILLATION APPARATUS (S'TEAM)

Cantion. Before remoring the flame from under the distilling flask or cutting off the steam (if steam is used for the distillation) remore the receiving flask so as to keep the liquid from being sucked back into the distilling flask when the flame is removed. Titrate the distillate with your standard $\mathrm{N} / 10 \mathrm{NaOH}$ solution, and from the data obtained, calculate the percentage of nitrogen in the feedstuff. The indicator, which should be cochineal or methyl red, may be placed in the receiver with the acid 

at the beginning of the distillation. Should the indicator show an alkaline reaction during the distillation, it means that not enough acid has been used to neutralize all the ammonia distilled. Multiply the percentage of nitrogen by 6.25 to obtain the percentage of crude protein in the sample. Rum duplicate determinations. The duplicate nitrogen determinations should check within .02 per cent.

Note. Accurate work requires that a blank digestion and distillation be made with some substance that is nitrogen free, in order to test the purity of the reagents.

\section{Questions}

1. Give reasons for the use of each substance in the determination of nitrogen. 2. Why multiply the percentage of nitrogen hy 6.25 to olotain the perentage of crude protein? Discuss.

\section{Experiment No. 20}

\section{DETERMINATION OF ETHER EXTRACT (FAT) IN}

\section{Apparatus} FEEDSTUFFS

One extraction thimble and extraction apluaratus.

Place 2 or :3 g. (weigherl exactly) of the sample of feeclstuff in an extraction thimble, and a small piece of cotton in the opening of the thimble to hold the feerlstuff in and also to distribute the ether during the extraction. Dry the thimble containing the feedstuff in the oven at the temperature of boiling water for two hours, to remove the moisture, and then extract with anlychous, alcoholfree ether* for twelve hours. Lse apparatus for the extraction as illustraterl in the lectures or specified by the instructor. The receiving flask for the fat should be cleaned, dried, and weigher before the extraction is begun.

* Prepared according to directions on page 89. 

After the extraction is complete, evaporate off the ether on a water bath from the receiving flask (recovering the ether, if possible), and dry the extract in the weighed vessel at

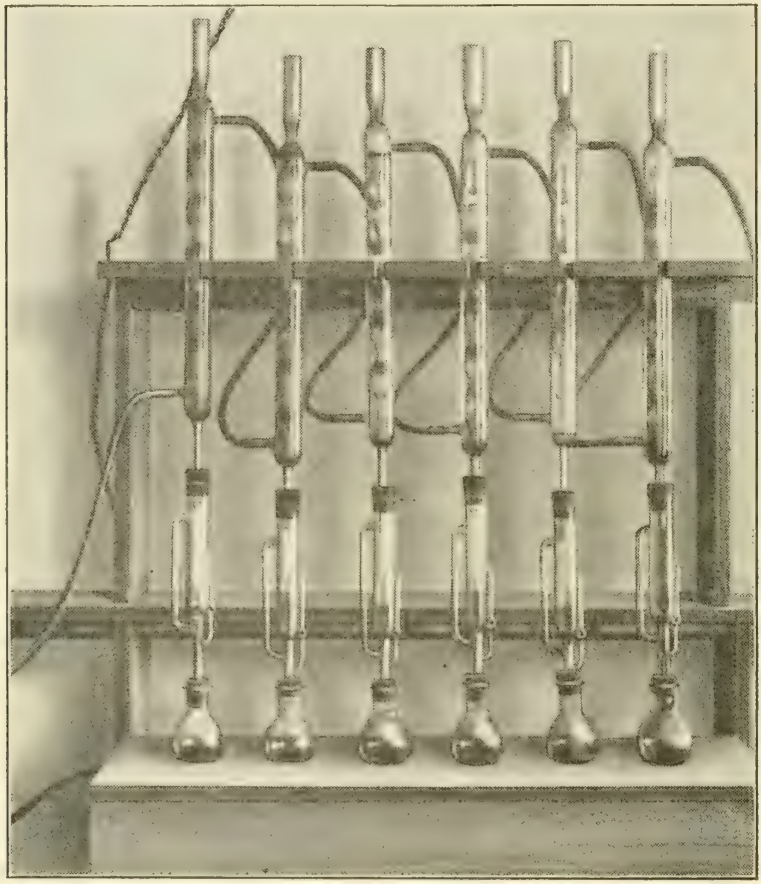

EX'TRACIION APPARATUS FOR DETERMINATION OF FAT (E'THER EXTRAC'T)

the temperature of boiling water for one-half hour; cool in desiccator and weigh. Repeat the drying and weighing at half-hour intervals until a constant minimum weight is obtained. The increased weight of the flask over the original weight of the flask when clean, empty, and dry is due to the weight of the fat extracted. 


\section{ExAMPLe}

Let $x=$ amount of feedstuff used.

Let $y=$ weight of flask plus weight of fat.

Let $z=$ weight of flask when empty, dry, and clean.

Then $y-z=$ weight of fat in $x \mathrm{~g}$. of feedstuff.

$\frac{y-\tilde{z}}{x} \times 100=$ percentage of ether extract (fat) in the feedstuff.

Make duplicate determinations. Calculate and report the percentage of ether extract in the sample of feedstuff.

NoтE. The term ether extract is used to represent the materials that are soluble in ether. Besides fats and oils the ether extract generally contains some waxes, resins, chlorophyll, coloring matters, and, in some cases, phosphorized fats and fatlike bodies containing both nitrogen and phosphorus.

\section{Questions}

1. What is ether? 2. How is it marle? 3. What are some of its properties:" 4. What impurities would most likely be found in ether? 5. How "an these impurities be most conveniently eliminated! 6. What are sulphuric ether and petroleum ether? 7. Name the other solvents which may be used for the extraction of fat, hesides ether, and give the temperature at which earh hoils. 8. Why is the heating value of a fat higher than that of a "arhohyliate? 9. Why is the feedstuff dried before the extraction of fiat, and why is anhydrous, alcoholfree ether used?

\section{Experiment No. 21}

PREPARATION OF A 1.25 PER CENT $\mathrm{H}_{2} \mathrm{SO}_{4}$ SOLUTION AND A 1.25 PER CENT NaOH SOLUTION

A 1.25 per cent sulphuric acid solution contains $12.5 \mathrm{~g}$. $\mathrm{H}_{2} \mathrm{SO}_{4}$ per liter. Determine the specific gravity of the C. P. concentrated sulphuric acid, and calculate the number of cubic centimeters of this solution that will contain $12.5 \mathrm{~g}$. of $\mathrm{H}_{2} \mathrm{SO}_{4}$ (see $A_{p}$ pendix, p. 85). Measure out the [28] 
calculated amount in a graduated cylinder, and dilute to one liter with distilled water. Titrate this solution against your standard alkali, and adjust the strength, if necessary, until the solution contains $0.0125 \mathrm{~g}$. of $\mathrm{H}_{2} \mathrm{SO}_{4}$ per cubic centimeter.

Weigh out the amount of $\mathrm{NaOH}$ (sticks, free of carbonates) required for a liter of a 1.25 per cent $\mathrm{NaOH}$ solution (the sticks of $\mathrm{NaOH}$ generally contain from 10 to 20 per cent water). Shake thoroughly until the $\mathrm{NaOH}$ is dissolved. Titrate this solution against the 1.25 per cent $\mathrm{H}_{2} \mathrm{SO}_{4}$ solution, and adjust the strength until correct.

\section{Questions}

1. 10 ce. of 1.25 per cent $\mathrm{H}_{2} \mathrm{SO}_{4}=$ (?) ce. $\mathrm{N} / 10 \mathrm{NaOH}$ ?

2. 10 cc. of 1.25 per cent $\mathrm{NaOH}=($ ?) ce. $\mathrm{N} / 5 \mathrm{HCl}$ ?

3.10 cc. of 1.25 per cent $\mathrm{H}_{2} \mathrm{SO}_{4}=(?)$ cc. 1.25 per cent $\mathrm{NaOH}$ ?

\section{Experiment No. 22}

\section{DETERMINATION OF CRUDE FIBER IN FEEDSTUFFS}

\section{Apparatus}

One 500 cc. Erlenmeyer flask; one condenser; two Gooch crucibles; 1.25 per cent $\mathrm{H}_{2} \mathrm{SO}_{4}$ solution; 1.25 per cent $\mathrm{NaOH}$ solution.

Place the residue from Experiment No. 20 in a $500 \mathrm{cc}$. Erlenmeyer flask. Add 200 cc. of boiling 1.25 per cent $\mathrm{H}_{2} \mathrm{SO}_{4}$ solution, connect with a reflux condenser, and boil gently for thirty minutes. Filter through a Gooch crucible containing a small quantity of asbestos, or a Büchmer funnel, using closely woven linen as a filter. Wash with boiling water until the washings are free from acid. Rinse the substance remaining in the crucible or on the linen back into the Erlenmeyer flask with 200 cc. of a boiling 

solution of 1.25 per cent $\mathrm{NaOH}$ (free from carbonates). Boil at once for thirty minutes as before. As soon as the boiling is completed, filter through a Gooch crucible or Büchner fumnel, as before, wash several times with boiling water, once with dilute HCI ( $1: 1)$, and then with boiling water until the washings are free from acid and are neutral. If linen is used as the filter, the material remaining on the linen has to be transferred to a porcelain crucible before drying. Dry the porcelain crucible or Gooch crucible containing the crude filser, asbestos, and mineral matter in an oven at the temperature of $110^{\circ} \mathrm{C}$. until completely dry, and weigh to constant weight. Then ignite the material in the porcelain crucible or Gooch crucible with a Bunsen flame, cool the crucible in a desiccator, and weigh to constant weight. The loss in weight represents the weight of the crude fiber in the sample of feedstuff examined. Make duplicate determinations. Calculate and report the percentage of crude fiber in the sample of feedstuff.

\section{Questions}

1. What is crude fiber? 2. Is it a compound or a mixture? 3. What sulstances are removed by each digestion? 4. Why

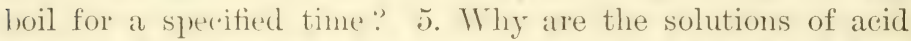
and alkali of this particular strength used, and why are they used in a certain order? 6. Discuss the value of the crudefiber determination in the consideration of the analysis of a feedstuff.

\section{Experiment No. 23}

DETERMINATION (IF NITROGEN-FREE EXTRACT IN FEEDSTUFF

Nitrogen-free extract is usually obtained by difference. Subtract from 100 per cent the sum of the percentage of moisture, ash, ether extract (fat), crucle fiber, and crude

$$
\text { [30] }
$$



protein. The result is the percentage of nitrogen-free extract in the sample.

Report the results in the following form:

Determination No. 1

Determination No. 2

Moisture

Ash

Ether extract.

Crude fiber

Crude protein

Total $\ldots x$

Total $x^{\prime}$

$100-x=$ percentage of nitrogen-free extract.

\section{Questions}

1. What substances constitute the nitrogen-free extract? 2. Nake a comparison of the analyses of two samples of feedstuff of the same kind, and give reasons for conclusions in regard to their feeding value. 3. A sample of feedstuff weighing $200 \mathrm{~g}$. after being air-dried weighed $50 \mathrm{~g}$. The analysis of the air-dried sample was as follows:

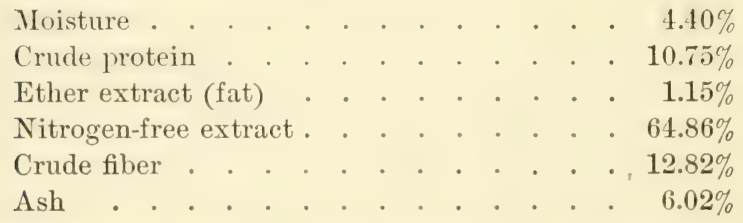

Report the analysis on the basis of the original material and also on the moisture-free basis. 



\section{PART III}

\section{CHEMICAL ANALYSIS OF SOIL}

\section{Directions for TAKING A SAMPLE OF SOIL FOR ANALYsis *}

Remove the surface accumulations of decaying leaves, etc., and take samples with a soil tube or auger to the desired deptlı. All samples of soils taken for analysis should be composite, and should be composed of representative samples taken from at least five different places in the field sample, each individual sample to be a column of uniform soil extending through the stratum sampled.

One composite sample should be taken from each important and distinctly different soil stratum to a depth of $40 \mathrm{in}$, or $1 \mathrm{~m}$., including a composite sample from the arable stratum, or plowed soil, usually about $6 \mathrm{in.}$, or $15 \mathrm{~cm}$., deep.

If the plow line and subsoil coincide, and the subsoil is fairly uniform stratum to a depth of about $40 \mathrm{in}$., then only two composite samples need be taken - one of the arable soil and one of the subsoil. But if the subsoil line is lower than the plow line and not below $40 \mathrm{in}$., then both strata below the arable soil should be sampled, which

* Bulletin No. 10 r (Reviserl), Bureau of Chemistry, United States Department of Agriculture. 

would make three composite samples from the field: one from the surface or arable soil, one from the subsurface soil (that is, from the stratum between the plow line and the true subsoil), and one from the true subsoil. Dry the samples in a well-aired, cool place.

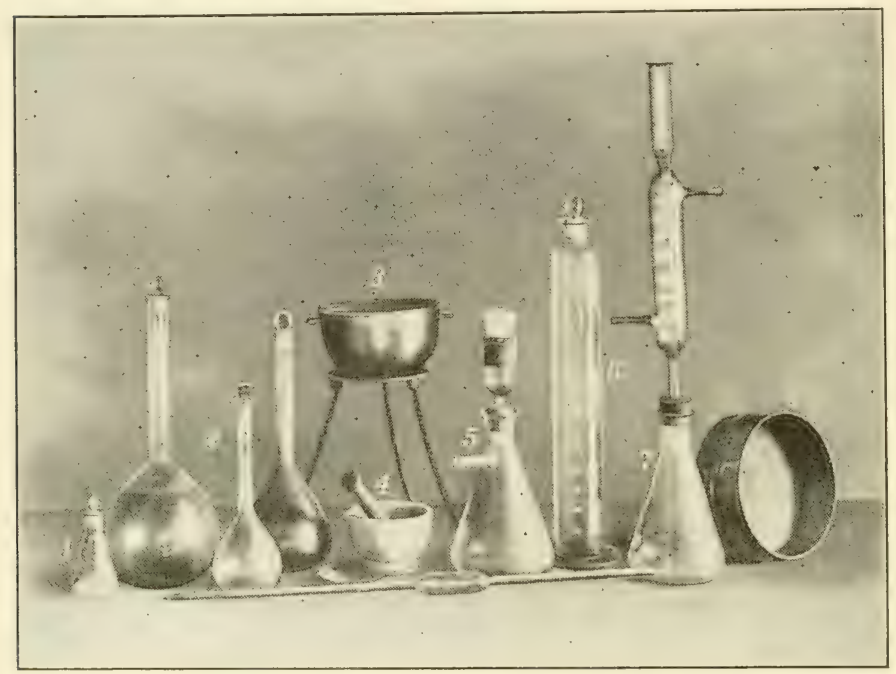

APPARATUS USED IN THE ANALYSIS OF SOILS

1, weighing bottle; $\therefore$, measuring flaskis (2.0) ee., 500 ce., and $1000 \mathrm{ce}$.); 3 , water bath and tripod; 4 , mortar and pestle; 5 , suction flask, funnel, and Gooch crucible; 6 , humus cylinder $(500 \mathrm{cc}$.$) ; 7$, flask with reflux condenser ; $\delta$, sieve (holes $1 \mathrm{~mm}$. in diameter)

\section{Preparation of Samples for Analysis}

Prepare the laboratory sample by putting it through a sieve with round holes of $1 \mathrm{~mm}$. diameter, using a rubbertipped pestle to pulverize the lumps. Weigh, and discard the remaining material. Keep the sample in a cool place, and stopper to prevent change in condition. The fine soil [33] 

that passes through the holes of the sieve is used for the chemical analysis. Record the weight of the fine and the coarse soil as obtained.

\section{Question}

Why is the weight of the fine and the coarse soil desired?

\section{Experiment No. 24}

\section{QUALITATIVE ANALYSIS OF SOIL}

Place about $10 \mathrm{~g}$. of soil in a beaker; then add $25 \mathrm{cc}$. of distilled water and 25 cc. of C. P. concentrated $\mathrm{HCl}$. Cover the beaker with a watch glass and heat on a sand bath, wire gauze, or hot plate in the hood for two hours, replacing the acid if excessive evaporation takes place. Dilute with $50 \mathrm{cc}$. of distilled water, heat to boiling, and filter the solution, washing the residue with hot water. The insoluble residue consists mainly of silica and insoluble silicates. Evaporate the filtrate to dryness to remove silica from the solution, take up with $25 \mathrm{cc}$. hot water containing $5 \mathrm{cc}$. of $\mathrm{HCl}$, and filter, washing the residue with hot water. Divide the filtrate into two portions: To Portion A add ammonium hydroxide $\left(\mathrm{NH}_{4} \mathrm{OH}\right)$ until alkaline. The precipitate may contain $\mathrm{Fe}(\mathrm{OH})_{3}$ (red), $\mathrm{Al}(\mathrm{OH})_{3}$ (white and flocculent), and calcium phosphate $\left(\mathrm{Ca}_{3}\left(\mathrm{PO}_{4}\right)_{2}\right)$ (white). Filter and test precipitate for iron and aluminium. Nake the filtrate alkaline with $\mathrm{NH}_{4} \mathrm{OH}$ and add the ammonium oxalate $\left(\left(\mathrm{NH}_{4}\right)_{2} \mathrm{C}_{2} \mathrm{O}_{4}\right)$ solution. A white precipitate of calcium oxalate $\left(\mathrm{CaC}_{2} \mathrm{O}_{4}\right)$ may form, shorving the presence of calcium. Make the filtrate from the calcium oxalate precipitation slightly acid with dilute $\mathrm{HCl}(1: 1)$, concentrate to a volume of about 30 ce., add 5 cc. of sodium

$$
\text { [34] }
$$



ammonium hydrogen phosphate, ${ }^{*}$ and then add gradually $\mathrm{NH}_{4} \mathrm{OH}$ until the solution is distinctly alkaline. If the soil contains a very small quantity of magnesium, it may be necessary to let the solution stand for a short time to obtain a precipitate. Evaporate Portion B nearly to dryness; add 20 cc. of water, make alkaline with $\mathrm{NH}_{4} \mathrm{OII}$, and then slightly acid with dilute $\operatorname{INO}_{3}(1: 1)$. IV arm to approximately $70^{\circ} \mathrm{C}$. and add a few cubic centimeters of ammonium molybdate $\left(\left(\mathrm{NH}_{4}\right)_{2} \mathrm{M}_{0} \mathrm{O}_{4}\right)$. A yellow precipitate of ammonium phosphomolybdate $\left(\left(\mathrm{NII}_{4}\right)_{3} \mathrm{PO}_{4} \cdot 12 \mathrm{MoO}_{3}\right)$ proves the presence of phosphates. Also test the original soil for carbonates. Make a detailed report of results, writing all equations illustrating the reactions.

\section{Questions}

1. In what chemical forms do the elements exist in a soil? 2. From what is the inorganic material or mineral matter of soils derived? 3. What elements are liable to be deficient in soils?

\section{Experiment No. 25}

\section{DETERMINATION OF MOISTURE IN SOIL}

Dry 2 to $5 \mathrm{~g}$. of air-dried soil in a weighed watch glass for five hours at the temperature of boiling water, cool in a desiccator, and weigh rapidly to avoid alsorption of moisture from the air. Heat again, and weigh at intervals of one hour until the material ceases to lose weight. Calculate and report the percentage of moisture in the soil.

* Prepared according to directions on page 89. 



\section{Experiment No. 26}

DETERMINATION OF VOLATILE MATTER IN SOIL

Weigh out 2 to $5 \mathrm{~g}$. of air-dried soil in a weighed porcelain crucible and heat to redness until all organic matter is burned. Cool the crucible containing the soil in a desiccator, and weigh. Continue the burning, cooling, and weighing until constant weight is obtained. If the soil contains appreciable quantities of carbonates, it should be moistened after cooling with a few drops of ammonium carbonate, dried, heated to dull reduess to expel ammonium salts, cooled in desiccator, and again weighed. The loss in weight represents the hygroscopic moisture (see Exp. No. 25), water of combination, organic matter, ammonium salts, etc. From this loss, calculated as percentage, subtract the percentage of moisture as determined in Experiment No. 25 and obtain the percentage of matter volatile above $100^{\circ} \mathrm{C}$. Make duplicate determinations. Calculate and report the percentage of volatile matter in the soil.

\section{Question}

Give the reason for the use of ammonium carbonate.

\section{Experiment No. 27}

\section{DETERMINATION OF HUMUS IN SOIL}

Place $10 \mathrm{~g}$. of the soil sample in a Gooch crucible or on a filter paper in a funnel, and wash with dilute $\mathrm{HCl}$ ( 1 cc. concentrated acid to 40 ce. $\mathrm{H}_{2} \mathrm{O}$ ) until the filtrate after being made alkaline with NII OII gives no precipitate with ammonium oxalate $\left(\left(\mathrm{NH}_{4}\right)_{2} \mathrm{C}_{2} \mathrm{O}_{4}\right)$ solution. [36] 

Wash with distilled water until free from acid. Transfer the contents of the crucible or funnel into a glass-stoppered cylinder, with $500 \mathrm{ce}$. of a 4 per cent $\mathrm{NI}_{4} \mathrm{OH}$ solution (1 ce. concentrated ammonia (sp. gr. .9) to 13 cc. of water), and allow it to remain, with occasional shaking, for twentyfour hours. During this time the cylinder should be inclined as much as possible without bringing its contents in contact with the stopper. Shake thoroughly and place the cylinder in a vertical position, add $2.5 \mathrm{~g}$. of $\left(\mathrm{NH}_{4}\right)_{2} \mathrm{CO}_{3}$, and leave it for at least twelve hours to allow the sediment to settle. Filter the supernatant liquid (that is, remove the liquid above the sediment without stirring the sediment up; the filtrate will be colored, but should be free from any sediment), evaporate an aliquot portion (say 50 cc.) to dryness in a small porcelain evaporating dish on a water bath, dry at $100^{\circ} \mathrm{C}$., and weigh. Ignite the residue, cool the dish in a desiccator, and weigh again. Calculate and report the pereentage of humus in sample.

\section{Questions}

1. What is humus? 2. What are humates? 3. What is humic acid? 4. Give reasons for each step in the determination. 5. Of what value is the humus determination? 6. Discuss the relation of organic matter in soils to fertility.

\section{Experiment No. 28}

\section{DETERMINATION OF NITROGEN IN SOIL (NITRATES ABSEN'T)}

Place $7 \mathrm{~g}$. of soil in an 800 ce. Kjeldahl digestion flask with $30 \mathrm{cc}$. concentrated C. P. sulphuric acid, and continue as in Experiment No. 19. Nake duplicate determinations. Calculate and report the percentage of nitrogen. 



\section{Experiment No. 29}

\section{TEST FOR ACIDITY OR ALKALINITY OF SOIL AND DETERMINATION OF LIME REQUIREMENTS}

Place about $10 \mathrm{~g}$. of soil in a beaker and add $75 \mathrm{cc}$. distilled water. After evaporating the filtrate to an approximate volume of $20 \mathrm{cc}$, stir for about five minutes and filter. Test the filtrate with phenolphthalein inclicator to see if the solution is alkaline or acid. If the solution is alkaline, then determine whether it is due to $\mathrm{Na}_{2}\left({ }^{\prime}()_{3}, \mathrm{Na}_{2} \mathrm{SC}_{4}\right.$, or $\mathrm{CaC}^{\prime}()_{3}$ in solution. If the solution is acid, then proceed as follows: Slake a small piece of lime (Ca()) until it falls to a fine powder. This is best done by adding a few drops of water' at a time, continuing until enough has been adced to slake the lime thoroughly. With the slaked lime (Ca(OII).2) make a saturated solution of limewater by the addition of approximately 250 ce. of warm water. Let the solution cool by standing; filter, and transfer the filtrate immediately to a glass-stoppered bottle. Titrate a portion of the clear solution with your standard $\mathrm{IICl}$ solution. Calculate and report the grams of $\mathrm{Ca}()$ per cubic centimeter of limewater.

The standardized limewater may be used to determine the lime requirements or the acidity of the soil as follows: Weigh out two portions of $10 \mathrm{~g}$. each, weighing only to the second decimal place; place them in two porcelain dishes of about $100 \mathrm{ec}$. capacity and moisten with about 75 cc. of distilled water; then to one add 5 ce. and to the other $10 \mathrm{cc}$. of the clear limewater solution from burette or pipette. Stir well, allow to stand about one hour, and then dry on a water bath. Arld 50 to 75 ce. of clistilled 
water, stir thoroughly, and filter. About $30 \mathrm{cc}$. of the filtrate is then placed in a porcelain dish, three drops of neutral phenolphthalein added, and the solution boiled over a direct flame until about $10 \mathrm{cc}$. remains in the dish. The portion showing the alkaline color of phenolphthalein with the least amount of limewater has been saturated with lime. The portion showing no color is still acid or neutral.

Next weigh out four more portions of soil and treat with limewater in a similar way, using for the first $1 \mathrm{cc}$. more of limewater than was used in the portion that did not show alkaline, for the second 2 ce. more, etc. These are carried through as in the first series.

Note the least number of cubic centimeters of limewater that saturated the $10 \mathrm{~g}$. of fine soil. From the data obtained, calculate and report the lime ( $\mathrm{CaO}$ ) required per acre of soil, using 2,000,000 1h. as the weight of an acre of soil 8 in. in (lepth. Also calculate the amount of ground limestone required per acre of soil.

\section{Questions}

1. Discuss soil acidity and alkalinity, including causes and eorrection. 2. If a soil solution tests acid with phenolphthalein as indicator when cold, and alkaline after boiling, what does this indicate? 3. Discuss the relation of the acidity of soils to soil fertility. 4. Give a complete discussion of alkali soils and the methods of correcting them.

\section{Experiment No. 30}

STRONG HYDROCHLORIC ACII) (SP. GR. 1.115) DIGESTION OF SOIL. PREPARATION OF SOIL SOLUTION

Weigh out exactly $10 \mathrm{~g}$. of soil, transfer to an Erlenmeyer flask of nonsoluble glass of 200 to 300 ce. capacity, and add $100 \mathrm{cc}$. of hydrochloric acid of constant boiling 

point (sp. gr. 1.115) made, approximately, by diluting 58 (*. of ordinary concentrated II('l (s). gr. 1.20) with 42 cc. of distilled water. The flask should be provided with a rubber stopper containing a glass tube about 20 in. in length. Place the flask containing the soil and acid in a water bath and digest for ten hours, shaking every hour while digesting. After the digestion is ('omplete, allow the insoluble residue to settle, and decant the solution into an evaporating dish. Very small quantities of sediment passing over will do no ham. IV ash the insoluble residue onto a filter with hot water, and continue the washing until free from chlorides, adding the washings to the original solution for evalporation. (It is advisable to let each portion in the filter paper rum through each time before ahling any more water.) $\lambda$ fter the addition of a few drops of nitric arid, to oxidlize the organic matter in solution, evaporate the solution to dryness on a water bath. 'Take up with hot water and a few cubic centimeters of hychochloric acid and again evaporate to complete dryness. When the evaporation is completed and the dish cooled, arde a few drops of strong hydrochloric acid, sufficient only to saturate the residue. Add about 20 ce. of water, warm on a water bath to secure complete solution, and filter, washing until free of chlorides. Again evaporate the solution to dryness, to render insoluble any silica that may be in solution, take up with hydrochloric acid and water as before, and filter into a 500 cc. measuring flask, washing the residue free from chlorides. Make the solution in the measuring flask up to the mark with (listilled water, shake thoroughly, and designate as Solution $A$. 


\section{Experiment No. 31}

\section{DETERMINATION OF IRON (Fe) IN SOIL SOLUTION BY VOLUMETRIC METHOD}

Measure out, with a burette or pipette, two $50 \mathrm{cc}$. portions of Solution A, place in beakers, heat nearly to boiling, and add NIIOII, drop by drop, until the solution is strongly alkaline. Boil for two minutes, and fiter white hut through a properly prepared Gooch crucible, washing several times with hot water (save filtrate and washings for Exp. No. 32). Transfer the precipitate and asbestos to the same beaker from which it was filtered, and add 25 ce. of $\mathrm{II}_{2}()_{4}(1: 4)$ to dissolve the precipitate. To this solution adll a small amomit of granulated zinc or zine dust and boil until all traces of zine have disappeared and the irom is completely reduced. Titrate the solution immertintel! with your standard $\mathrm{KMnO}_{4}$ solution. If the reduced iron solution is allowed to stand exposed to the air before titrating, it will become oxidizerl. From the results obtained, calculate and report the percentage of iron in the soil sample soluble in the acid solution.

\section{Questions}

1. Give the reason why $\mathrm{K}_{\mathrm{MnO}}$ acts as its own indicator. 2. What effect would a small amount of zinc in the solution have on the determination? 3. Write equations illustrating all the reactions, and explain each step. 


\section{Experiment No. 32}

\section{DETERMINATION ()F CALCIUM (Ca) IN SOIL SOLUTION BY VOLUMETRIC METHOD}

Evaporate the filtrate and washings from Experiment No. 31 to a volume of about 50 ('., make slightly alkaline with $\mathrm{NH}_{4}() \mathrm{II}$, and while boiling add ammonium oxalate $\left(\left(\mathrm{NI}_{4}\right)_{2} \mathrm{C}_{2} \mathrm{O}_{4}\right)$ solution dropurise until all the calcium is precipitated, then add ? ce. in excess. Isoil for five minutes, allow the precipitate to settle, and filter while hot on a filter paper, without using suction. Wash the precipitate and beaker free from soluble oxalates with hot urater. Transfer filter paper and contents to the same beaker from which the precipitate was filtered, ark $50 \mathrm{ce}$. of distilled water and 20 (ce. of $\mathrm{II}_{2} \mathrm{~s}()_{4}(1: 1)$, heat nererly to boiling, and while still hot titrate with the standard K.Mno () solution. ('alculate and report the percentage of lime (Ca() ) in the soil sample soluble in the acid solution, and also its expivalent in calcium carbonate ( ( $\left.\mathrm{aCO}_{8}\right)_{3}$.

Nоте. If preferred, the calcium can be determined directly upon solution $\triangle 1$ in the following manner: Take sol ce. of Solution A, make slightly alkaline with $\mathrm{NII}_{4}$ ()II, and just elear with dilute IICl, aroiding an coress. II eat to boiling, and powdered ammonium oxalate or ammonium oxalate solution until the calcium is all precipitated, and let stand until cool (usually until the next period or overnight). Filter, wash, and titrate the precipitate as in the previous method.

\section{Question}

Write equations for all reactions taking place in the determination. 



\section{Experiment No. 33}

\section{DETERMINATION OF PHOSPHORIC ACID $\left(\mathrm{P}_{2} \mathrm{O}_{5}\right)$ IN SOIL SOLUTION BY GRAVIMETRIC METHOD*}

Measure out, with a pipette or burette, two 100 cc. portions of Solution A into beakers, and concentrate to a volume of about one fourth. Make alkaline with $\mathrm{NH}_{4} \mathrm{OII}$, then add $10 \mathrm{ce}$. in excess, and make stightly acid with $\mathrm{HNO}_{3}(1: 1)$, using a small piece of litmus paper in the solution as indicator. Aroid much excess of nitric acid. Gradually add to $20 \mathrm{ce}$. of the ammonium molybdate solution ${ }^{\dagger}$ the solution containing the phosphates, and place the beaker in the water bath at the temperature of $40^{\circ}$ to $60^{\circ} \mathrm{C}$. (he sure to transfer the last trace of the phosphate solution from the beaker by rinsing with distilled water). When the precipitate has sufficiently settled, add a few cubic centimeters of the ammonium molybate solution to the supernatint liquid, in order to be sure that all the phosphoric acid is precipitated. If any precipitate is produced, add more ammonium molybdate solution and repeat the operation until all the phosphoric acid is precipitated. After standing for three hours at a temperature not above $60^{\circ}$ C., filter on a small filter paper and wash with cold water until free from acid. Dissolve the ammonium phosphomolybdate precipitate on the filter paper by pouring a solution containing equal parts of ammonium hydroxide and hot water through the filter, receiving the solution in the beaker in which the first precipitation took place.

* If desired, phosphoric acid $\left(\mathrm{P}_{2}\left(\mathrm{O}_{5}\right)\right.$ can be determined by optional method (Exp. No. $33 a$ ).

$\dagger$ Prepared according to directions on page 89. 

Be sure that all the yellow precipitate on the filter paper is dissolved, and do not allow the total volume of the filtrate to amount to more than $100 \mathrm{cc}$. Make the solution slightly acid with hydrochloric acid, using a small piece of litmus paper in the solution as indicator, and then slightly alkaline with $\mathrm{NH}_{4} \mathrm{OH}$. Cool the solution and add magnesia mixture ${ }^{*}$ (from 10 to 15 ce.) from a burette or pipette, letting it run in at the rate of a drop per second, stirring the solution vigorously with a policeman, or rubbertipped glass rod, at the same time. After fifteen minutes add 12 ce. of ammonium hydroxide (sp. gr. 0.90) and allow the solution to stand several hours - two hours is usually enough. (If more convenient, the solution may be covered with a watch glass and left until the next laboratory period before filtering.) Filter and wash the precipitate with 2.5 per cent ammonia $\left(\mathrm{NII}_{3}\right)$ solution until free from chlorides. After the precipitate is chied, place the filter paper and precipitate in a weighed crucible and ignite to whiteness. Cool in desiccator, weigh, and heat to constant weight. From the weight of magnesium pyrophosphate $\left(\mathrm{Mg}_{2} \mathrm{P}_{2} \mathrm{O}_{7}\right)$ calculate the weight and the percentage of phosphoric acid $\left(\mathrm{P}_{2} \mathrm{O}_{5}\right)$ in the soil soluble in the acid solution.

\section{Questions}

1. Write equations for each step in the determination. 2. Discuss the term phosphoric acid $\left(\mathrm{P}_{2} \mathrm{O}_{5}\right)$ as used. 3. Show the difference between a 2.5 per cent ammonia solution and a 2.5 per cent ammonium hydroxide solution.

* Prepared according to directions on page 91 . 



\section{Experiment No. $33 a$ (Optional Method)}

\section{DETERMINATION OF PHOSPHORIC ACID $\left(\mathrm{P}_{2} \mathrm{O}_{5}\right)$ IN SOIL SOLUTION BY VOLUMETRIC METHOD}

Measure out, with a pipette or burette, two 100 cc. portions of Solution A into beaker's, and concentrate to a volume of about one fourth. Make alkaline with $\mathrm{NH}_{4} \mathrm{OH}$, then add 10 ce. in excess, and make slightly acid with $\mathrm{HNO}_{3}(1: 1)$, using a small piece of litmus paper in the solution as indicator. Aroid much exess of IINO). Gradually ard to $20 \mathrm{ce}$. of the ammonium molyblate solution the solution containing the phosphates, and place the beaker in a water bath at the temperature of $40^{\circ}$ to $60^{\circ} \mathrm{C}$. (be sure to transfer the last trace of the phosphate solution from the beaker ly rinsing with distilled water). When the precipitate has sufficiently settled, add a few cubic centimeters of the ammonium molyblate solution to the supernatant liquid, in order to be sure that all the phosphoric acid is precipitated. If any precipitate is produced, add more ammonium molybdate solution, and repeat the operation until all the phosphoric acid is precipitated. After the solution containing the precipitate stands for three hours at a temperature not above $60^{\circ} \mathrm{C}$., filter on a small filter paper and wash with cold water until free from acid. Transfer the precipitate and filter paper containing the precipitate back into the same beaker in which it was precipitated. From the burette add the standard $\mathrm{NaOH}$ solution until the yellow precipitate is completely dissolved. Add about $25 \mathrm{cc}$. of distilled water and a few drops of phenolphthalein indicator.

$$
\text { [45] }
$$



1. Should the solution be colorless with the indicator added, continue the addition of the $\mathrm{NaOH}$ solution until a permanent pink color is obtained; that is, the end-point is reached.

2. Should the solution be colored after the indicator is added, that is, alkaline, titrate with your standard $\mathrm{HCl}$ solution until the color is discharged, and then titrate with your standard $\mathrm{NaOH}$ solution until the end-point is obtained.

In either case the total amount of $\mathrm{NaOII}$ used to dissolve and titrute the yellow precipitate and also the total amount of standard IICl used should be recorded. The precipitate is dissolved in the standard $\mathrm{NaOH}$ solution according to the following equation:

$\left(\mathrm{NH}_{4}\right)_{3} \mathrm{PO}_{4} \cdot 12 \mathrm{MoO}_{3}+23 \mathrm{NaOH}$

$=11 \mathrm{Na}_{2} \mathrm{MoO}_{4}+\left(\mathrm{NH}_{4}\right)_{2} \mathrm{MoO}_{4}+\mathrm{NaNH}_{4} \mathrm{HPO}_{4}+11 \mathrm{H}_{2} \mathrm{O}$

Two parts of ammonium phosphomolybdate

$$
\left(\left(\mathrm{NH}_{4}\right)_{3} \mathrm{PO}_{4} \cdot 12 \mathrm{MoO}_{3}\right)
$$

contain 1 part of phosphoric acid $\left(\mathrm{P}_{2} \mathrm{O}_{5}\right)$.

Mol. wt. $\mathrm{P}_{2} \mathrm{O}_{5}$ : mol. wt. $46 \mathrm{NaOH}:: x:$ ce. of $\mathrm{NaOH} \times$ the titre of the $\mathrm{NaOH}$ solution

$x=$ grams of phosphoric acid $\left(\mathrm{P}_{2} \mathrm{O}_{5}\right)$ in the aliquot portion of the soil solution. From the data obtained, the titre of the $\mathrm{NaOH}$ solution, and the equation, calculate and report the percentage of phosphoric acid $\left(\mathrm{P}_{2} \mathrm{O}_{5}\right)$ in the soil soluble in the acid solution.

\section{Question}

Give the reason for each step in the determination and write equations illustrating the reactions.

$$
\text { [46 ] }
$$





\section{Experiment No. 34}

\section{DETERMINATION OF POTASH $\left(\mathrm{K}_{2} \mathrm{O}\right)$ IN SOIL SOLUTION BY THE USE OF PLATINUM SOLUTION*}

Measure out, with a burette or pipette, two 100 cc. portions of Solution A, place in beakers, heat nearly to boiling, and add $\mathrm{NH}_{4} \mathrm{OH}$, drop by drop, until the solution is strongly alkaline. Cover the beaker and boil the solution for about one minute; if no ammonia is given off (detect by smelling), more is added, drop by drop, until it can be detected. I) not allow the precipitate to settle, but stir and filter immediately while hot, washing it thoroughly with hut unater. Evaporate the filtrate and washings to complete dryness, heat below redness to expel ammonium salts, dissolve in about $25 \mathrm{cc}$. of liot water, add about 5 ece of saturated barium hydroxide, and heat to boiling. Let the solution stand until the precipitate settles, and test the supernatant liquid with a drop of barium hydroxide solution to be sure that precipitation is complete. When the precipitation is complete, filter and wash the residue thoroughly with hot water. While the solution is boiling add anmonium hydroxide and ammonium carbonate to precipitate the barium. Allow the solution to stand for a short time on a water bath, filter, wash the precipitate thoroughly with hot water, and evaporate filtrate and washings to dryness. Expel the ammonium salts by heating at a low red heat as before, dissolve the residue in about $20 \mathrm{cc}$. of water, add about $2 \mathrm{ce}$. of ammonium

* If desired, potash can be determined hy optional methods (Exps. Nos. $34 a, 34 b)$.

$$
\text { [47] }
$$



hydroxide and a drop of ammonium carbonate solution, let stand on a water bath for a few minutes, and filter into an evaporating dish. Evaporate filtrate and washings nearly to dryness, add $1 \mathrm{cc}$. of dilute $\mathrm{H}_{2} \mathrm{SO}_{4}(1: 1)$, evaporate to dryness, and ignite to whiteness. As all the potassium is in the form of sulphate, no loss need be apprehended by volatilization of potash, and a full red heat must be maintained until the residue is perfectly white. Dissolve the residue in about $15 \mathrm{ec}$ of water, add a few drops of hydrochloric acid, and platinum solution $\left(\mathrm{H}_{2} \mathrm{PtCl}_{6}\right)^{*}$ in slight excess (avoid the use of too large an excess, as the reagent is very expensive). Evaporate on a water bath to a thick paste, and treat the residue with 80 per cent alcohol (sp. gr. 0.8645 ). If enough platinum solution has been added to precipitate all the potassium, the alcoholie solution will be slightly colored. If the alcohol is not slightly colored, it must be evaporated off, the precipitate reclissolved in water containing a few drops of $\mathrm{HCl}$, more platinum solution adder, and again evaporated to a thick paste and treated with alcohol as before. If the alcoholic solution is not colored, owing to an excess of platinum solution, do not add more platinum solution directly to the alcoholic solution, but evaporate off the alcohol first. Also aroid the absorption of ammonia by the solution. After the precipitate is treated with the 80 per cent alcohol, filter into a properly prepared and weighed Gooch crucible, wash thoroughly with 80 per cent alcohol, then with $10 \mathrm{cc}$. of the special ammonium chloride solution ${ }^{\dagger}$ to remove impurities. Repeat washing with the special ammonium chloride solution about five times, and

* Prepared according to directions on page 90.

$\dagger$ Prepared according to directions on page 90. 
again wash thoroughly with 80 per cent alcohol. Dry the precipitate for thirty minutes at the temperature of boiling water, cool in desiccator, and weigh. The precipitate is potassium platinic chloride $\left(\mathrm{K}_{2} \mathrm{Pt}\left(\mathrm{C}_{6}\right)\right.$, and should be perfectly soluble in water (which gives a means of checking the results if desired). For the conversion of potassium platinic chloricle to potassium oxide $\left(\mathrm{K}_{2} \mathrm{O}\right)$ use the factor 0.1941. Calculate and report the percentage of potash $\left(\mathrm{K}_{2} \mathrm{O}\right)$ in the soil soluble in the acid solution. (Save all filtrates and potassium platinic chloricle precipitates so as to recover the platinum.)

\section{Questions}

1. How is the factor 0.1941 obtained? 2. Write equations illustrating each step in the determination.

\section{Experiment No. $34 a$ (Optional Method)}

\section{DETERMINATION OF P(OTASH (K, ()) IN SOLL SOLLTION BY VOLUMETRIC METHOD *}

Measure out, with a burette or pipette, two $100 \mathrm{cc}$. portions of Solution A, place in beakers, heat to boiling, add $\mathrm{NH}_{t} \mathrm{OII}$, drop by drop, until the solution is strongly alkaline, and a few (ublic centimeters of ammonium oxalate solution. Cover the beaker and boil the solution for about one minute; if no ammonia is given off (detect by smelling), more is added, drop by drop, until it can be detected. Do not allow the precipitate to settle, but stir and filter immediately while hot, washing it thoroughly with hot water.

* Most of the points in the manipulation were taken directly from a method suggested by (). M. Shedd for the determination of total potassium in soils, Joumul of Industrial and Engincering Chemistry, Vol. I, No. 5, May, 1909. 

Evaporate the filtrate and washings nearly to dryness in an evaporating dish, add $1 \mathrm{cc}$. of dilute $\mathrm{H}_{2} \mathrm{SO}_{4}(1: 1)$, evaporate to dryness, and ignite to whiteness by maintaining a full red heat until the residue is perfectly white.

Dissolve the residue in hot water, filter if necessary to remove any insoluble material, acidify the clear solution slightly with acetic acid, and evaporate to a volume of about 10 or 15 cc.* Ten cubic centimeters or a liberal excess of the cobaltinitrite reagent, prepared according to Adie and Wood, are added slowly, so that the precipitate may not be too finely divided, and the liquid evaporated off on the water bath to a sirupy consistency, becoming solid on cooling. It is important not to heat longer than is necessary. After cooling, the soluble matters are dissolved in about $25 \mathrm{cc}$. of cold water (which should give a brown solution, showing excess of reagent), the solution decanted through a carefully prepared Gooch crucible, ${ }^{\dagger}$ and this operation repeated until the dish and any precipitate remaining in it have been thoroughly washed. $\ddagger$ Be sure that all the precipitate is completely removed from the dish. After washing the filter, the contents of the crucible (the asbestos with the precipitate) are transferred to a $500 \mathrm{cc}$. beaker and well broken up by stirring with a glass rod in a little water. If any of the precipitate adheres to the Gooch crucible so that it cannot be washed off, the crucible also is to be put into the dish. A measured excess

* When the reagent is added to a dilute solution, it is decomposed before the potassium salt is precipitated. In small volumes this does not happen.

$\dagger$ The asbestos pulp for making the filter should be just fine enough to hold the precipitate and be free from very fine particles.

$\ddagger$ A half-saturated solution of common salt may be used instead of water if there is trouble in filtering the precipitate. 

of standard potassium permanganate solution * (usually 20-40 cc.) is now run in, and the whole diluted to about eight or ten times the volume of permanganate added, the dish covered, and its contents heated to boiling over a free flame or on a hot plate, with frequent stirring for about ten minutes, or until the potassium cobaltinitrite is oxidized completely. It has been found that the oxidation requires a somewhat longer time than the five to eight minutes recommended by Drushel, apparently because it is hard to separate the yellow potassium precipitate from the asbestos so that the permanganate can come in contact with it. When the oxidation is complete - as indicated by the darkening of the solution and the separation of the manganese hychroxide - about 15 ce. of dilute sulphuric acid $(1: 7)$ are adcled and allowed to act three or four minutes to favor oxidation of the last traces of cobaltinitrite. ${ }^{\dagger} \mathrm{A}$ measured excess of the standard oxalic acid $\ddagger$ containing 50 ce. of concentrated sulphuric acid to the liter is then run in, and the liquid liept at the same temperature until all the manganic hydroxide has been dissolved and the solution is colorless. At this point it will be seen by the absence or presence of the yellow potassium compound whether the oxidation of the cobaltinitrite precipitate was complete. The excess of oxalic acid is now titrated with the standard permanganate solution. $s$ The total volume of permanganate solution used, less that equivalent to the oxalic acid added, gives the amount used up in oxidizing

* See Experiment No. 15 (approximate N/10 solution).

$\dagger$ The sulphuric acid is not to be added at first, along with the permanganate, as the action would be very rapid and some cobaltinitrite might escape oxidation.

$\ddagger$ Prepared according to directions on page 90 .

$\S$ See Experiment No. 15. 

the cobaltinitrite; and this, multiplied by the appropriate factor, gives the weight of potassium obtained. One cubic centimeter of $\mathrm{N} / 10$ permanganate solution is equivalent to $0.000711 \mathrm{~g}$. of $\mathrm{K}$, or $0.000856 \mathrm{~g}$. of $\mathrm{K}_{2} \mathrm{O}$. If the potassium permanganate solution used for the titration is not exactly $\mathrm{N} / 10$, then it is necessary to calculate the appropriate factor to be used. It is also necessary to carry out a blank experiment, under the same conditions as the analysis, using the same quantities of the reagents, and to subtract the small amount of permanganate solution consumed from that found in the analysis. From the results obtained, calculate and report the percentage of potash $\left(\mathrm{K}_{2} \mathrm{O}\right)$ in the sample of soil soluble in the acid solution.

\section{Question}

How is the factor for the $\mathrm{K}$ equivalent of $1 \mathrm{cc} . \mathrm{N} / 10 \mathrm{KMO}_{4}$ obtained?

\section{Experiment No. $34 b$ (Optional Method)}

\section{DETERMINATION OF POTASII (K.2O) IN SOIL SOLUTION BY THE USE OF PLATINUM SOLU'TION*}

Measure out, with a burette or pipette, two $100 \mathrm{cc}$. portions of Solution $A$ into glazed porcelain evaporating dishes, add $10 \mathrm{ec}$. concentrated C. P. hydrochloric acid, and evaporate to dryness. Take up with 10 to $15 \mathrm{cc}$. of distilled water, add about 5 ce. of platinum chloride solution and 2 or $3 \mathrm{cc}$. of hydrochloric acid, and evaporate to dryness or to a thick paste on a water bath. Remove the dish from the water bath and let stand until it is

* This method is a molification of the method propesed by C. C. Moore, Journal of American Chemical Society, Vol. XX (1898), p. 340, and of the method used in the laboratories of the Texas Experiment Station.

$$
\text { [52] }
$$



perfectly cold. Add from 10 to 30 cc. of "acid alcohol," * according to the amount of precipitate in the dish. All other materials besicle the precipitate of potassium platinic chloride should be completely dissolved. If there is heat evolved when the acid alcohol is added, more alcohol is added to cool the solution, as this reaction often forms a white insoluble substance which would ruin the results. If enough platinum solution has been added to precipitate all the potassium, the alcoholic solution will be slightly colored. If the alcohol is not slightly colored, it has to be evaporated off, the precipitate redissolved in distilled water containing a few clrops of hychochloric acid, more platinum solution arderl, and again evaporated to a thick paste and the solution treated with acid alcohol, as before. If the alcoholic solution is not colored, owing to an excess of platinum solution, do not add more platinum solution directly to the alcoholic solution, but evaporate off the alcohol first. After the precipitate is treated with acid alcohol, filter by decantation into a properly prepared and weighed Gooch crucible; wash once with acid alcohol, then with 95 per cent alcohol until the alcohol wash does not dissolve any more colored material of any kind; pour the washings through the crucible each time, but leave the precipitate in the evaporating dish as far as possible. Add $10 \mathrm{cc}$ of special ammonium chloride solution ${ }^{\dagger}$ to the precipitate in the dish, let stand a few minutes so as to dissolve impurities, and pour off the solution through the Gooch crucible. Repeat the washing with the special ammonium chloride solution about five times and again

* 10 cc. of concentrated C. P. hydrochloric acid solution added to 100 cc. of 95 per cent alcohol.

$\dagger$ Prepared according to directions on page 90. 

wash thoroughly with 95 per cent alcohol. Transfer the potassium platinic chloride precipitate from the dish to the Gooch crucible by the use of 95 per cent alcohol, washing the side of the crucible carefully so as to remove any adhering solution of ammonium chloride. Dry the precipitate for thirty minutes at the temperature of boiling water, cool in desiccator, and weigh. The precipitate is potassium platinic chloride $\left(\mathrm{K}_{2} \mathrm{PtCl}_{6}\right)$, and should be perfectly soluble in water (which gives a means of checking the results if desired). For the conversion of platinic chloride to potassium oxide $\left(\mathrm{K}_{2}()\right)$ use the factor 0.1941 . Calculate and report the percentage of potash $\left(\mathrm{K}_{2} \mathrm{O}\right)$ in the soil soluble in the acid solution. (Save all filtrates and potassium platinic chloride precipitates so as to recover the platinum.)

Note. "Available" phosphoric acid and potash in soils can be determined by digestion with 1 per cent eitric acid (I)yer's method). Journal of American ('hemical Society, Vol. LXVI (1894), p. 115; Lunge, Technical Methods of Chemical Analysis, Vol. I, p. 852. 



\section{PART IV}

\section{ANALISIS OF FERTILIZERS}

\section{Preparation of Sample of Fertilizer for} AnAlysis *

Grind the sample fine enough to pass through a sieve having circular perforations $1 \mathrm{~mm}$. in clianeter, and then mix thoroughly. Perform the grinding and sifting as rapinlly as possible to aroid loss or gain during the operation. After the sample is prepared and thoroughly mixed, it should be kept in a well-stoppered bottle. Enough sample should be prepared for all the determinations.

\section{Experiment No. 35}

DETERMINATION OF MOISTURE IN FERTILIZER

Weigh out exactly $2 \mathrm{~g}$. of the fertilizer in a weighed watch glass and dry for three hours at the temperature of boiling water; cool in desiccator, and weigh rapidly. IJeat again at intervals of one-half hour until the material ceases to lose weight. Make duplicate determinations. Calculate and report the percentage of moisture in the sample of fertilizer.

* Bulletin No. 10r (Revised), Bureau of Chemistry, United States Department of Agriculture.

$$
\text { [55] }
$$





\section{Experiment No. 36}

PREPARATION OF A STANDARD NAOH SOLUTION FOR PHOSPHORIC ACID $\left(\mathrm{P}_{2} \mathrm{O}_{5}\right)$ DETERMINATION

Make up a solution (500 ce.) of sodium hydroxide ( $\mathrm{NaOH})$ so that $10 \mathrm{ce}$. of this solution should neutralize 16.2 ('c. of an excetly N/5 IIC'1 solution. If your standard hydrochloric acid solution is not extertly $\mathrm{N} / \tilde{\delta}$, then calculate the number of colbic centimeters of ymur $H\left(C^{\prime} l\right.$ solution

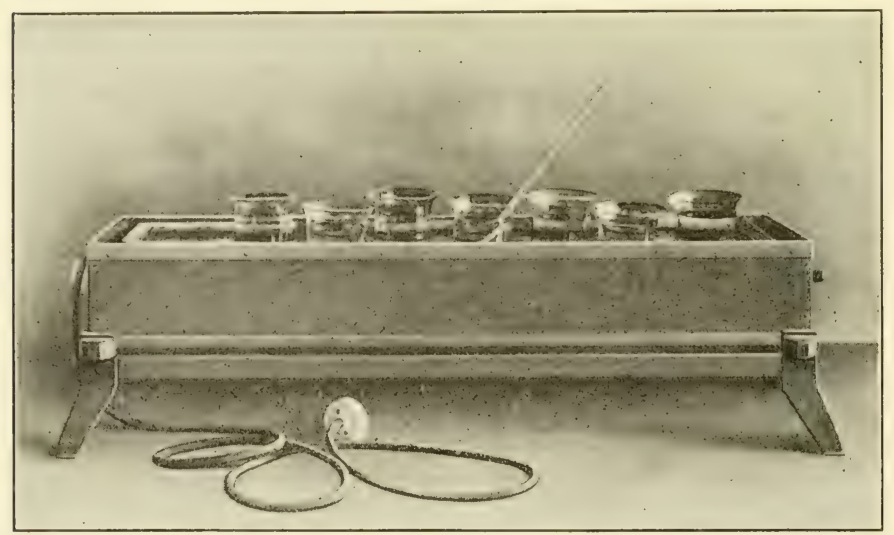

COMBINATION ELECTRIC WATER BATH AND HOT PLATE

which will be equimalent to 16.2 ce. of an exactly $\mathrm{N} / 5 \mathrm{HCl}$ solution. Standardize the NaOII solution so that $10 \mathrm{cc}$. of it will exactly neutralize the calculated number of cubic centimeters of your standard acid. One cubic centimeter of the NaOII solution will then be equivalent to $.001 \mathrm{~g}$. of phosphoric acid $\left(\mathrm{P}_{2} \mathrm{O}_{5}\right)$. 



\section{Question}

Show that 1 ce. of the NaOH solution is equivalent to $.001 \mathrm{~g}$. of $\mathrm{P}_{2} \mathrm{O}_{5}$.

Note. For equation see Experiment No. $33 a$.

\section{Experiment No. 37}

DETERMINATION OF TOTAL PIOSPHORIC ACID $\left(\mathrm{P}_{2} \mathrm{O}_{5}\right)$ IN FER'TILIZER

Weigh out $2 \mathrm{~g}$. of the sample of fertilizer and place it in a beaker with 15 to ? 2 (". of encentrated hychrochloric acid and from 3 to 10 ce. of concentrated nitric acid, and digest from 20 to 30 minutes under the homl. After the solution is (omplete, cool, arld 2.) ce. of distilled water, filter, and wash the resilue thoroughly, allowing the washings and the original solution to run into a 250 ce. measuriny flusk. Malie ul to the mark with distilled water, stopper the flask, and shake thoroughly. Measure out, with a burette or pipette, two $25 \mathrm{ce}$. portions into beakers for analysis, and to each portion add 2.) (ce. of clistilled water. Make allialine with $\mathrm{NH}_{4} \mathrm{OH}$, adling $10 \mathrm{ce}$. in excess, and then sliyltly arid with $\operatorname{INO}_{3}(1: 1)$, using a small piece of litmus paper in the solution as indieator. Avoid much excess of IINO. Wrarm the solution to the temperature of $60^{\circ}$ to $65^{\circ}(C$ hy standing the beakers in a pan containing warm water. After the solution has reached the required temperature add $30 \mathrm{cc}$. of ammonium molybdate solution; stir, and let stand for fifteen minutes in the warm water at $60^{\circ}$ to $6.5^{\circ} \mathrm{C}$. Filter at once and wash twice with water by decantation, by pouring the solution through the filter, using 25 to $30 \mathrm{cc}$. of water each time, agitating the precipitate thoroughly, and allowing it 

to settle. Transfer to the filter paper and wash with cold water until washings are free from acid. (Test by means of litmus paper.) Transfer the filter paper containing the precipitate back into the beaker in which it was precipitated. From the burette add your standard $\mathrm{NaOH}$ solution (prepared for the $\mathrm{P}_{2} \mathrm{O}_{5}$ determination) until the yellow precipitate is completely dissolved. Adl about $25 \mathrm{cc}$. of distilled water and a few drops of phenolphthalein indicator.

1. Should the solution be colorless with the indicator added, continue the ardition of $\mathrm{Na}() \mathrm{I}$ solution until a permanent pink color is obtained ; that is, the end-point is reached.

2. Should the solution be colored after the inclicator is added, that is, alkaline, titrate with your standard HCl solution until the color is discharged, and then titrate with your standard NaOII solution until the end-point is obtained.

In either case the total amount of NaOII used to dissolve and titrate the yellow precipitate and also the total amount of standard IIC'l used should be recorded. From the data obtained calenlate and report the percentage of phosphorie acid $\left(\mathrm{P}_{2} \mathrm{O}_{5}\right)$ in the sample of fertilizer.

\section{Questions}

1. Give the reason for each step in the determination and write equations for the reactions. 2. Define raw rock phosphate, basic slag, acid phosphate, water-soluble phosphoric acid, reverted phosphoric acil, insoluble phosphoric acid, and give their chemical compositions and methods of preparation. 



\section{Experiment No. 38}

DETERMINATION OF WATER-SOLUBLE PHOSPHORIC ACID $\left(\mathrm{P}_{2} \mathrm{O}_{5}\right)$ IN FERTILIZER

Weigh out $2 \mathrm{~g}$. of the sample, place it on a $9 \mathrm{~cm}$. filter paper, and leach with successive small portions of distilled water into a 2j0 ce. mersuring flusk (allowing each portion of water to rum through before adding more) until the filtrate measures nearly $250 \mathrm{ce}$. If the filtrate is turbid, add a few drops of concentrated $\mathrm{INO}_{3}$. Make up to the mark with distilled water and shake the solution thoroughly. Measure out, with burette or pipette, two 25 ce. portions into beaker's and proceed as in Experiment No. 37. stave the resitue in the filter puper for Experiment $\Lambda_{0 .} 39$.

\section{Experiment No. 39}

DETERAINATION ()F CITRATE-SOLLBLE PHOSPHORIC ACID $\left(\mathrm{P}_{2} \mathrm{O}_{5}\right)$ IN FERTILIZER

Teat $100 \mathrm{ce}$ of strictly neutral ammonium citrate solution * (sp. gr. 1.09) to $6 \tilde{5}^{\circ}$ ( $\mathrm{\text {Cina }} 200$ to 300 ce. Erlenmeyer flask placed in a warm water hath, keeping the flask loosery stoppered. When the citrate solution has reached the temperature of $\left(i \tilde{5}^{\circ} \mathrm{C}\right.$., drol $)$ into it the filter paper containing the learled rexilue from the water-soluble phosphoric acid determination (Exp. No. 38), close tightly with a smooth rubber stopper, and shake violently until the filter paper is reduced to a pulp. Place the flask in the bath, and maintain it at such a temperature (about $67^{\circ} \mathrm{C}$.)

* Prepared according to directions on page 91.

$$
\text { [59] }
$$



that the contents of the flask will stand exactly at $65^{\circ} \mathrm{C}$. Shake the flask every five minutes. At the expiration of excetly thirty minutes from the time the filter with contents was introduced, remove the flask from the bath and filter as rapidly as possible. Wash the residue and flask thoroughly with distilled water heated to the temperature of $65^{\circ} \mathrm{C}$. Return the filter with contents to the Erlenmeyer flask, ald $30 \mathrm{ce}$. of concentrated $\mathrm{INNO}_{3}$ and $10 \mathrm{cc}$. of concentrated $\mathrm{HCl}$, and digest under the hood until phosphates are dissolved ; that is, about twenty or thirty minutes. Dilute with io (ce. of distilled water, and filter into a $250 \mathrm{cec}$ mensurin!y flusk, washing the residue thoroughly. Make up with distilled water to the mark, shake thoroughly, and measure out, with burette or pipette, two 25 ce. portions into two beakers. Then proceed as in Experiment No. 37. The total phosphoric acid minus the sum of the water-soluble and citrate-insoluble gives the citratesoluble phosphoric acirl. Calculate and report the percentage of citrate-insoluble and (itrate-soluble phosphoric acid $\left(\mathrm{P}_{2} \mathrm{O}_{5}\right)$ in the sample of fertilizer.

\section{Questions}

1. Give the formulas for molybdic arid, ammonium molybdate, ammonium phosphomolyblite, and citrate-soluble phosphoric acid. 2. Write the equation for the reaction of ammonium phosphomolybdate and TaOII. 3. Diseuss the solubility of monocalcium, dicalcium, and tricalcium phosphate. 4. Define "available" phosphoric acid. 



\section{Experiment No. 40}

\section{DETERMINATION OF POTASH $\left(\mathrm{K}_{2} \mathrm{O}\right)$ IN A MIXED FERTI-}

LIZER BY THE USE OF PLATINUM SOLUTION*

Boil $5 \mathrm{~g}$. of the fertilizer sample with $300 \mathrm{cc}$. of distilled water thirty minutes. Add to the hot solution a slight excess of $\mathrm{NH}_{4} \mathrm{OH}$ and then sufficient ammonium oxalate solution to precipitate all the lime present. Cool, dilute to $500 \mathrm{cc}$. with distilled water in a measuring flask, shake thoroughly, and filter through a dry filter. Evaporate in an evaporating dish $100 \mathrm{ce}$. of the solution (measured exactly and corresponding to $1 \mathrm{~g}$. of the sample) nearly to dryness, add $1 \mathrm{cc}$ of dilute sulphuric acid ( $1: 1)$, evaporate to dryness (being careful not to lose anything by spattering), and ignite to whiteness. As all the potassium is in the form of sulphate, no loss need be apprehended by volatilization of potash, and a full red heat must be maintained until the residue is perfectly white. Dissolve the residue in hot water and filter if any insoluble material remains. Add to the clear solution a few drops of $\mathrm{HCl}$, and platinum solution $\left(\mathrm{H}_{2} \mathrm{PtCl}_{6}\right)^{\dagger}$ in slight excess. Evaporate on a water bath to a thick paste and treat the residue with 80 per cent alcohol (sp. gr. 0.8645). If enough platinum solution has been added to precipitate all the potassium, the alcoholic solution will be slightly colored. If the alcohol added to the residue is not slightly colored, the alcohol has to be evaporated off, residue redissolved in water containing a few drops of $\mathrm{HCl}$, more platinum

* Potash can be determined by optional method (Exp. No. $40 a$ ).

$\dagger$ Prepared according to directions on page 90 . 

solution added, and the solution again evaporated to a thick paste and treated with alcohol. Do not add more platinum solution to the alcoholic solution before evaporating off the alcohol. Arovid the absorption of ammonia by the solution. After the residue is treated with 80 per cent alcohol, filter into a properly prepared and weighed Gooch crucible and wash the precipitate thoroughly with 80 per cent alcohol, then with 10 ac. of the special ammonium chloricle solution,"* to remove impurities. Repeat washing with $10 \mathrm{cc}$ portions of special ammonimm chloride solution about five times, and again wash thoroughly with the alcoholic solution. Dry the precipitate for thirty minutes at the temperature of boiling water, cool in desiccator, and weigh. The precipitate is potassium platinie chloride ( $\mathrm{K}_{2} \mathrm{Pt}\left(\mathrm{Cl}_{6}\right.$ ) and should be perfectly soluble in water (which gives a means of checking the results if desired). For the conversion of potassium platinic alloricle $\left(\mathrm{K}_{2} \mathrm{P}+\mathrm{Cl}_{6}\right)$ to potassium oxide ( $\left.K_{2}()\right)$ use the factor 0.1941 . From data obtained, alculate and report the percentage of potash $\left(\mathrm{K}_{2} \mathrm{O}\right)$ in the sample of fertilizer. (Save all the filtrates and potassium platinice chloride precipitates so as to recover the platinum.)

\section{Experiment No. ${ }_{2}^{40} a$ (Optional Method)}

DETERMINATION OF P(OTASII (K,O) IN MIXED FERTILIZTR BY VOLUMETRIC METHOD

Measure out into evaporating dishes, with a burette or pipette, two 25 ce. portions of the filtered potassium solution preparerl in Experiment No. 40. Evaporate each portion nearly to dryness in an evaporating dish, add $1 \mathrm{ce}$.

* Prepared according to directions on page 90. 
of dilute sulphuric acid $(1: 1)$, evaporate to dryness, and ignite to whiteness by maintaining a full red heat until the residue is perfectly white. Dissolve the residue in hot water, filter if any remains undissolved, acidify the clear solution slightly with acetic acid, and proceed in the same manner as in Experiment No. $34 a$. From data obtained calculate and report the percentage of potash $\left(\mathrm{K}_{2} \mathrm{O}\right)$ in the sample of fertilizer.

\section{Experiment No. 41}

DETERMINATION OF NITROGEN IN FERTILIZERS (NITRATES PRESENT)

Weigh out exactly 1 to $2 \mathrm{~g}$. of the sample and transfer to an $800 \mathrm{ce}$. K jeldahl flask. Ard $30 \mathrm{ce}$. salicylic acid solution* and $5 \mathrm{~g}$. of sodium thiosulphate. Heat over a low flame until all danger of frothing has passed, cool, and then add about $10 \mathrm{~g}$. of $\mathrm{K}_{2} \mathrm{SO}_{4}$ and about .5 g. copper sulphate $\left(\mathrm{C} u S O_{4} \cdot 5 \mathrm{II}_{2} \mathrm{O}\right)$. Continue the digestion until the material is completely oxidized. Make the distillation and titration as given in Experiment No. 19. Make duplicate determinations. From data obtained, calculate and report the percentage of nitrogen in the sarnple of fertilizer.

\section{Questions}

1. Explain the use of salicylic acid and sodium thiosulphate. Write equations illustrating. 2. Explain the other steps in the determination.

* Prepared according to directions on page 91 . 


\section{PART V}

\section{ANALTSIS OF INSE(TICIDE AND FUNGICII)E}

\section{Experiment No. 42}

\section{PREPARATION ANI) S'TANDARIOIZATION OF SOLUTION FOR DETERMINATION OF ARSENIOLS OXIDE (AS.2) \\ IN PARIS GREEN}

Stareh solution for indirator. Place $1 \mathrm{~g}$. of starch in 10 ce. of cold distilled water to separate the granules, and then pour this mixture into 100 ce. of boiling water. Boil for five minutes, stirring continuously.

Stambard iodine solution. I) issolve about 3.5 $\mathrm{g}$. of iodine in 200 ce. of distilled water in which has been dissolved from 8 to $10 \mathrm{~g}$. of pure potassium iodicle (KI). Dilute to a volume of $\tilde{\delta} 00$ c.e. with distilled water and shake thoroughly.

Before standardizing be sure that all the iorline is in solution. Dissolve exartly $1 \mathrm{~g}$. of pure arsenious oxide $\left(\mathrm{As}_{2} \mathrm{O}_{3}\right)$ in 50 ce. of $\mathrm{HCl}(1: 1)$, heating rapidly if necessary to bring all the arsenic into solution. (Do not boil the solution.) Cool and make up to a volume of $250 \mathrm{cc}$. in a measuring flask. Perform the titration as follows: Measure out, with a burette or pipette, two portions of $25 \mathrm{cc}$. of the arsenious oxide $\left(\mathrm{As}_{2} \mathrm{O}_{3}\right)$ solution into porcelain evaporating dishes (about 6 in. in diameter) or into

$$
\text { [64] }
$$



large beakers, add about $300 \mathrm{cc}$. of distilled water, and sodium bicarbonate $\left(\mathrm{NaHCO}_{3}\right)$ in slight excess. Add the iodine solution from a burette, using the starch solution as an indicator. The titration is complete when you obtain the first permanent blue color. Make at least two titrations. Calculate the strength of the iodine solution in terms of arsenious oxide $\left(\mathrm{As}_{2} \mathrm{O}_{3}\right)$.

\section{Question}

Why should the hydrochlorie acid solution of arsenious oxide not be boiled?

\section{Experiment No. 43}

DETERMINATION OF TOTAL ARSENIOLS OXIDE $\left(\mathrm{As}_{2} \mathrm{O}_{3}\right)$ IN PARIS GREEN

To determine the total arsenious oxide in Paris green use $2 \mathrm{~g}$. and proceed exuctly as with the arsenious oxide in the standardization of iodine solution (Exp. No. 42). Make duplicate determinations. Calculate and report the percentage of arsenious oxicle $\left(\mathrm{As}_{2} \mathrm{O}_{3}\right)$ in the sample of Paris green.

\section{Questions}

1. Is Paris green a compound or a mixture? 2. If a compound, what is its formula? 3. To what is the $\mathrm{As}_{2} \mathrm{O}_{3}$ oxidized by the iodine? 4. Give equations for the reaction. 5. How much $\mathrm{As}_{2} \mathrm{O}_{3}$ can Paris green contain and still be safe as an insecticide? 6. Give a simple test for the purity of Paris green. 


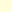




\section{Experiment No. 44}

DETERMINATION OF WATER-SOLUBLE ARSENIOUS OXIDE $\left(\mathrm{As}_{2} \mathrm{O}_{3}\right)$ IN PARIS GREEN

Place $1 \mathrm{~g}$. of Paris green (weighed exactly) in a large flask with excetly $500 \mathrm{ec}$. of distilled water (previously boiled to expel carbon dioxide and then cooled to room temperature). Stopper the flask, shake thoroughly, and let stand for one week, shaking as often as convenient. At the end of this time filter the solution through a dry filter. Dilute $100 \mathrm{ce}$. of the filtrate with $100 \mathrm{cec}$ of distilled water, add sodimm bicarbonate (NaIIC(O) in stiygt excess, and titrate with your standard iodine solution in the same mamner as in Experiment No. 42,2 , using the starch solution as inclicator. Make duplicate titrations. Calculate and report the percentage of water-soluble arsenious oxide $\left(\mathrm{As}_{2} \mathrm{O}_{3}\right)$ in the sample of Paris green.

\section{Anativsis of Lead Arsenate*}

Preparation of sample. If the sample is in the form of a paste (as it usually is), dry the whole sample to constant weight at the temperature of boiling water and record the results as total moisture. Frind the dry sample (which will gain a small amount of moisture during grinding) to a fine powder and determine the various constituents as follows:

* These methods are modifications of methods proposed by Haywood, Bulletin No. 105, Bureau of Chemistry, United States Department of Agriculture (1907), p. 165. 


\section{Experiment No. 45}

\section{DETERMINATION OF MOISTURE IN LEAD ARSENATE}

Heat $2 \mathrm{~g}$. of the sample in the water oven at the temperature of boiling water for eight hours or in the hotair oven at $110^{\circ} \mathrm{C}$. for from five to six hours or till constant weight is obtained. Make duplicate determinations. Calculate and report the percentage of moisture in the sample of lead arsenate.

\section{Experiment No. 46}

\section{DETERMINATION OF TOTAL LEAD OXIDE IN LEAD ARSENATE}

Dissolve $2 \mathrm{~g}$. of the sample in about $80 \mathrm{cc}$. of water and 15 cc. of concentrated nitric acid on the steam or water bath; transfer the solution to a $250 \mathrm{cc}$. measuring flask and make up to the mark. To $50 \mathrm{cc}$. of the solution add $3 \mathrm{cc}$. of concentrated sulphuric acid; evaporate on the steam bath to a sirupy consistency and then on a hot plate till white fumes appear and all nitric acid has been driven off. Add $50 \mathrm{ce}$. of water and $100 \mathrm{cc}$. of 95 per cent alcohol, let stand for several hours, and filter off the supernatant liquid; wash about ten times with acidified alcohol (water 100 parts, 95 per cent alcohol 200 parts, and concentrated sulphuric acid 3 parts) and then with 95 per cent alcohol * till free from sulphuric acid. Dry, transfer as much as possible of the precipitate from the paper into a weighed crucible, and ignite at a low red

* Prepared according to directions on page 92.

[67 ] 

heat. Burn the paper in a separate porcelain crucible, and treat the residue first with a little nitric acid, which is afterwards evaporated off, and then with a drop or two of sulphuric acid. Ignite, weigh, and add this weight to the weight of the precipitate previously removed from the paper for the amount of the lead sulphate. Calculate and report the percentage of leal oxide in the sample of lead arsenate.

\section{Question}

Write equations for the chemistry of each step in the determination.

\section{Experiment No. 47}

DETERMINATION OF WATER-SOLLBLE LEAD OXIDE IN LEAD ARSENATE

Weigh out $2 \mathrm{~g}$. of the learl arsenate, place in a flask with $2000 \mathrm{ce}$ of carbon-dioxide-free water, and let stand for a week, shaking as often as convenient (eight times a day if possible). Filter through a diy filter and use aliquots (200 to $400 \mathrm{ce}$.) of this solution for determining soluble lead oxide and arsenic oxide $\left(\mathrm{As}_{2} \mathrm{O}_{5}\right)$; determine lead as described in Experiment No. 46 for total lead oxide, using the same relative proportions of sulphuric acid, water, and alcohol, hut lieeping the rolume as small as possible. Make duplieate determinations. C'alculate and report the perentage of water-soluble lead oxide in the sample of lead arsenate. 



\section{Experiment No. 48}

DETERMINATION OF TOTAL ARSENIC OXIDE $\left(\mathrm{As}_{2} \mathrm{O}_{5}\right)$ IN LEAD ARSENATE

Transfer $100 \mathrm{cc}$. of the nitric acid solution of the sample, prepared as in the determination of lead (Exp. No. 46), to a porcelain dish, add $6 \mathrm{cc}$. of concentrated sulphuric acid, evaporate on the water bath to a sirupy consistency and then on a hot plate until the appearance of white fumes of sulphuric acid. Wash into a $100 \mathrm{cc}$. flask with water, make up to the mark with distilled water, filter through a dry filter, and use $50 \mathrm{cc}$. aliquot parts for further work. Transfer this to an Erlenmeyer flask of 400 cc. capacity, add 4 cc. of concentrated sulphuric acid and $1 \mathrm{~g}$. of potassium iodide, dilute to about $100 \mathrm{cc}$, and boil until the volume is reduced to about $40 \mathrm{ce}$. Cool the solution under running water, dilute to about $300 \mathrm{cc}$, and exactly use up the iodine set free and still remaining in the solution with a few drops of approximately tenth-normal sodium thiosulphate solution. Be careful that an excess of sodium thiosulphate is not used. Wash the mixture into a large beaker, make alkaline with sodium carbonate, and slightly acidify with dilute sulphuric acid, using up all the sodium carbonate; then make alkaline with an excess of sodium bicarbonate. Titrate the solution with your standard iodine solution until a blue color appears, using the starch solution as indicator. Calculate and report the percentage of arsenic oxide $\left(\mathrm{As}_{2} \mathrm{O}_{5}\right)$ in the sample of lead arsenate. 


\section{Questions}

1. Discuss the commercial preparation of lead arsenate and varieties. 2. Name the desirable properties of an insecticide. 3. Write equations for the chemistry of each step in the determination.

\section{Experiment No. 49}

DETERMINATION OF WATER-SOLLBLE ARSENIC OXIDE $\left(\mathrm{As}_{2} \mathrm{O}_{5}\right)$ IN LEAD ARSENATE

For this determination use 200 to $400 \mathrm{ce}$. of the water extract obtained under the determination of soluble lead oxide (Exp). No. 47). Add 0.5) (火. of sulphuric acid and evaporate to a sirupy consistency, then heat on a hot plate until white fumes appear. Aild a very small amount of distilled water, and filter throngh a small filter paper to remove the lead, using as little wash water as possible. Place this filtrate in an Erlenmeyer flask, and determine arsenic, as described above, for total arsenic oxide, using the same amount of reagents and the same dilutions. Calculate and report the pereentage of water-soluble arsenic oxide $\left(\mathrm{As}_{2} \mathrm{O}_{5}\right)$ in the sample of lead arsenate.

\section{Experiment No. 50}

TESTING BORDEALX MIXTLRE FOIR SOLLBLE COPPER

Take a small piece of quicklime (Ca()) and slake it with water. Weigh out on the rough balance about $5 \mathrm{~g}$. of copper sulphate $\left(\mathrm{CuSO}_{4} \cdot 5 \mathrm{II}_{2} \mathrm{O}\right)$ and dissolve in about 100 cc. of water. Add the milk of lime to the copper sulphate solution until you (annot obtain a test with potassium ferrocyanicle $\left(\mathrm{K}_{4} \mathrm{Fe}(\mathrm{CN})_{6}\right){ }^{*}$ (The test for * Prepared according to directions on page 92 . 

soluble copper should be made by using small filtered portions taken from the original mixture.) This is known as Bordeaux mixture. Take a portion of the mixture, dilute it with water, and pass carbon dioxide into it for about fifteen minutes. Again test the solution for soluble copper.

\section{Questions}

1. Explain your results. 2. Also make the test for soluble copper by adding a drop of dilute ammonia to the clear solution, noting the blue copper hydroxide. Add more ammonia and observe the soluble blue compound. 3. How does the carbon dioxide of the air cause bad effects with Bordeaux mixture? 4. How could you prevent it? 5. Discuss the composition of Bordeaux mixture and the killing of foliage by its use as a spray. 6. With what insecticides can it be used? 



\section{PART VI}

\section{ANALYSIS OF MILK}

\section{Experiment No. 51}

\section{DETERMINATION OF SPECIFIC GRAVITY OF MILK}

The simple of milk is thoroughly mixed and poured into a cylinder or hychometer jar. I)etermine first the temperature of the milk ancl then, by means of a hydrometer or lactometer, determine the specific gravity. The hydrometer or lactomeder should be gently lowered into the milk and the reating observerl from the top of the meniscus. The tomperature of the milk should be adjusted to $15.5^{\circ}$ ( $!$. Defore the reading is marle, or the correction for the temperature should be made so as to record the specific gravity rearling at the temperature of 15.5 $)^{\circ}$ C. or 60$)^{\circ}$ F. The (2nereme and New York Board of Health lactometers are used to the largest extent for this determination. 'T'o prevent the milk from souring before the other determinations are marle, add 1 ce. of formalin (t0 per cent solution of formalclehyle) to one pint of the milk, and lieep the bottle stoppered.

\section{Questions}

1. That is specific grarity? 2. Name four ways of determining specific gravity of a liquid. 3. Explain the effect of 

watering and skimming (and the two combined) upon the specific gravity.

\section{References}

LeACH. Food Inspection and Analysis.

Richmond. Dairy Chemistry.

VAN SLYKE. Modern Methods of Testing Milk and Milk Products.

Wiley. Agricultural Analysis, Vol. III.

\section{Experiment No. 52}

\section{DETERMINATION OF TOTAL SOLIDS IN MILK}

Measure out, with a burette or pipette, $10 \mathrm{cc}$. of milk of known specific gravity into a tared flat-bottomed dish of not less than $5 \mathrm{~cm}$. diameter. Evaporate to dryness on a water bath, and dry in water oven for three hours at the temperature of boiling water. Cool in desiccator and weigh rapidly. IIeat again at intervals of one-half hour until the material ceases to lose weight. Make duplicate determinations. Calculate and report the percentage of total solids in the sample of milk.

\section{Questions}

1. What does the total solids of milk contain? 2. The milk residue should be nearly pure white (a brownish color shows decomposition). Explain. 2. What effect would the souring of milk have on the content of the total solids in the milk? Explain.

\section{Experiment No. 53}

\section{DETERMINATION OF ASH IN MILK}

Measure out, with a burette or pipette, two 25 cc. portions of milk into weighed porcelain dishes. Add $5 \mathrm{cc}$. of concentrated $\mathrm{HNO}_{3}$, evaporate to dryness, and ignite at 

a temperature just below redness until the ash is free of carbon. Cool in desiccator and weigh. Make duplicate determinations. Calculate and report the percentage of ash in the sample.

\section{Question}

What does the ash of milk contain?

\section{Experiment No. 54}

DETERAINATION OF FAT IN MILK BY TIEE WERNERSCHMIDT METHOD

Transfer $10 \mathrm{ce}$ of milk, mectsured arenretely, to a large test tube (5) ce. (apacity), add 10 ce. of concentrated IICl, cork tightly, shake thoroughly, and heat in a water bath for about ten minntes, with frequent shaking, until the liquid is of a deep-brown color. The heating must not be continued too long. Cool the tulne thoroughly in a stream of water, add about $30 \mathrm{cc}$. of ether, and shake vigorously. Allow to stand until the ether layer, which contains the fat, has separated out. Transfer as much as possible of the ether layer, withont disturbing the other layer, to a weighed flask (this may comveniently be done by closing the test tube with a cork provided with small glass tubes similar to a wash bottle, the larger tube arlapted to slide up and down in the cork and turned up slightly at the bottom. When the ether layer is ready to be transferred to the flask, the sliding tube is arranged so that it terminates just above the division of the two layers, and the ether is then blown out into the weighed flask). Add $10 \mathrm{cc}$. of ether to the test tube and shake again. Transfer this ether layer to the weighed flask. In the same manner make two more

$$
\text { [74] }
$$



extractions and transfer the ether layer to the weighed flask as before. Evaporate off the ether in the weighed flask, dry at the temperature of boiling water until free of ether, cool in desiccator, and weigh. Make duplicate determinations. Calculate and report the percentage of fat in the sample.

\section{Questions}

1. Name and describe two other methods for the determination of fat in milk. 2. If the sample of milk is slightly churned, how would you proceed to determine the fat content?

\section{Experiment No. 55}

DETERMINATION OF TOTAL PROTEIN (CASEIN AND ALBUMIN) IN MILK

Measure out, with a burette or pipette, two 5 cc. portions of milk into Kjeldahl flasks, and proceed with the digestion, distillation, and titration as in Experiment No. 19. Multiply the percentage of nitrogen by 6.38 to obtain the percentage of total protein in milk. Calculate and report the percentage of total protein in the sample.

\section{Question}

How was the factor 6.38 obtained?

\section{Experiment No. 56}

\section{DETERMINATION OF CASEIN IN MILK}

Measure out, with a burette or pipette, two $10 \mathrm{cc}$. portions of milk into beakers, dilute with distilled water to a volume of $100 \mathrm{cc}$., heat to a temperature of $40^{\circ}$ to $42^{\circ} \mathrm{C}$., and add at once $1.5 \mathrm{cc}$. of an approximate 10 per cent 
acetic acid solution. Stir with a rubber-tipped glass rod, or policeman, and let stand for about five minutes, then decant on filter, wash thoroughly with cold water by decantation (pouring the washings through the filter paper each time), and transfer precipitate completely to filter. The filtrate should be clear or very nearly so. If it is not clear when it is first run through, it should again be filtered through the same filter and washed as before. Transfer the filter paper and contents to Ki jeldlahl flasks and proceed with the digestion, distillation, and titration as in Experiment $\mathrm{N}_{0}$. 19. Multiply the percentage of nitrogen by 6.38 to olotain the percentage of casein in the milk. Calculate and report the percentage of casein in the sample.

\section{Questions}

1. What is the federal standard for milk? the state standard? 2. What is the composition of "ow"'s milk? 3. How does it differ from human milk"' t. How is cow's milk modified for infants? J. What fiats shown hy an analysis would influence you to believe that a sample of milk had been skimmed? watered"' skimmed and wateresl:' 6. To what is the acidity of milk due? 7 . What is the composition of Cheddar cheese? 8. Give the commercial uses of casein.

\section{Reference}

LeAcir. Food Inspection and Analysis (3d ed.), p. 160. 1914.

Noте. Casein may be determined by volumetric methods: Walker, Journal of Industrial and Engineering Chemistry, Vol. VI,

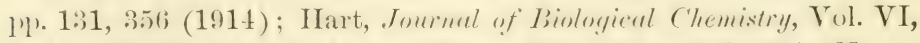
1. 445) (1909); Van Slyke and Bosworth, Technical Bulletin No. 10 (1909), New York (Geneva) Experiment Station. 


\section{PART VII}

\section{A BRIEF SANITARY ENAMINATION OF IVATER}

\section{Experiment No. 57}

\section{DETERMINATION OF TOTAL SOLIDS IN WATER}

Evaporate $200 \mathrm{ce}$ of water in a small evaporating dish on a water bath (a portion of the total volume can be evaporated, then more adderl until the total amount is evaporated). Dry at $105^{\circ}$ ( $\mathrm{\text { }}$. in an oren until weight is constant, cool in desiceator, and weigh. Calculate and report parts of total solids per million parts of water, also in terms of grains per gallon.

\section{Qualitative Analysis}

Test the residue for phosphates, chlorides, sulphates, iron, aluminium, magnesium, and calcium.

\section{Experiment No. 58}

DETERMINATION OF CILLORINE AS CIIU(IIDES IN WATER

Measure out, with a pipette or burette, 50 cc. of water into each of two small beakers or evaporating dishes. Add from three to four drops of potassium chromate solution (10 per cent) as an indicator, coloring the contents of each beaker exactly alike. Place the beakers on a white surface. Titrate the water in the beakers with standard 
silver nitrate $\left(\mathrm{AgNO}_{3}\right)$ solution. Add one drop at a time, and continue the titration with frequent agitation until the water shows the first tinge of red. Make duplicate determinations. If convenient, the titration should be performed under a yellow light or by wearing yellow-colored goggles. Calculate and report parts of chlorine and its equivalent in $\mathrm{NaCl}$ per million parts of water.

\section{Questions}

1. If the water contains orer a parts of chlorine per 100,000 parts of water, what is suspereted? Discuss. 2. What is the chlorine content of sea water? 3. What is the sanitary significance of the chlorine content of water?" t. Write equattions illustrating all rearetions. 5. State the relative solubilities of silver chloride and silver chromate.

\section{Experiment No. 59}

DETECTION OF FREE AMMONIA IN WATER

To 25 ce. of water in a tall test tube arde 5 ce. of Nessler's reagent * and note the color. Only a faint yellow tinge should be visible. A deeper color or turbidity generally indicates animal contamination. Compare the treated sample with the untreated sample in a similar tube. The experiment can be made quantitatively by comparing the color of the sample with different samples of distilled water containing known amounts of ammonium chloride $\left(\mathrm{NH}_{4} \mathrm{Cl}\right)$.

\section{Questions}

1. Of what does Nessler's reagent consist? 2. Define free and albuminoid ammonia. 3. How is albuminoid ammonia determined? 4. Discuss the significance of free and albuminoid ammonia in water.

* Prepared according to directions on page 92 . 



\section{Experiment No. 60}

\section{DETECTION OF NITRITES IN WATER}

Into a large test tube place a drop of $\mathrm{HCl}, 2 \mathrm{cc}$. sulphanilic acid* and equal volumes of naphthylamine hydrochloride, ${ }^{*}$ and $50 \mathrm{cc}$. of the water under examination. If a red color is produced immediately or within twenty minutes, the presence of nitrites is assured. $\Lambda$ s a rule nitrites are not found in good water. Any water containing nitrites should be suspected of being contaminated. Why? The test tube should be corked to avoid contamination from laboratory atmosphere.

\section{Experiment No. 61}

\section{DETECTION OF NITRA'TES IN WATER}

Evaporate $100 \mathrm{ce}$ of the sample to dryness in an evaporating dish over a water bath. Treat with 1 (') of phenolsulphonie acid, *stirring thoroughly. Adr 10 c.e. of distilled water and half as much NIIOH. In the presence of nitrates the characteristic color (yellow) of the ammonia salt of nitrophenol-sulphonic acid is formed. Nitrates are present in almost all natural waters. Why ?

* Prepared according to directions on page 93 or hy a methoul proposed by Chamot, Pratt, and Redfield in an article entitled "A Stully on the Phenolsulphuric Acid Method for the Determination of Nitrates in Water" (a modified phenolsulphuric acid method), Joumul of Amerirun Chemicul society, Vol. XXXIII, No.3(1911). 'The reagent when prepared by the method recommented by Chamot, Pratt, and Redfield consists of the diacid with only traces of monoacids. This method is especially desirable when the reagent is to be user for quantitative work, as the method of preparation given in this manual yields a mixed product. 
$$
\text { . }
$$ 


\section{Experiment No. 62}

\section{DETERAINATION OF ABSORBED OXYGEN IN WATER}

Place 100 ce. of water in a beaker and add 10 drops of $\mathrm{H}_{2} \mathrm{SO}_{4}$. Warm gently and add the standard solution (K.Mn() ${ }_{4}$ ), (lrop by drop (stirring constantly). As soon as the first tinge of pink alpears, warm the beaker again and notice if the color is permanent. The first tinge of permanent pink denotes the end of the operation. The test should be limited to about fifteen minutes.

This determination gives reliable information concerning the amount of organic contamination, but does not distinguish between that of vegetable and animal origin. If more than one grain per gallon is absorbed, the water is probably polluted.

\section{Experiment No. 63}

DETERMINATION OF TEMPORARY IIARDNESS OR ALKALINITY OF WATER

Titrate $100 \mathrm{ce}$ of water with your standard solution of IICl, using methyl orange or erythrosin and chloroform as indicator. Calculate and report results in parts of calcium carbonate $\left(\mathrm{CaCO}_{3}\right)$ per 100,000 parts of water, giving the so-called degrees of hardness. If sodium or potassium carbonates are present, they will also react alkaline, but a correction for this error can be obtained by determining permanent hardness.

\section{Reference}

OLsEn. Quantitative Chemical Analysis. 


$$
\text { . }
$$




\section{Questions}

1. What is hard water? 2. Define permanent hardness and temporary hardness. 3. Give another way in which the hardness of water may be determined. 4. Give the essential determinations on water for the following purposes: (1) drinking, (2) boiler, (3) irrigation. 5. State the lenefits derived from each. 6. Discuss the correction of undesirable properties of waters used for different purposes. 


\section{PART VIII}

\section{APPENDIX}

\section{BOOKS OF REFERENCE}

Arman, C. M. Milk, its Nature and Composition.

Allen, A. H. Commercial Organic Analysis. 4 vols.

Allyn, L. B. Elementary Applied Chemistry.

Blyti, A. W. Foods, their Composition and Analysis.

Bulletin No. 10'y (Revised) (1907), Bureau of Chemistry, United

States Department of $A$ griculture. "Methods of $A$ nalysis adopted

by the Association of Official Agricultural Chemists."

Imulletin No. 65 (19)(2), Bureau of Chemistry, United states Depart-

ment of Agriculture. "Provisional Methods for the Analysis

of Foods adopted by the Association of Official Agricultural

Chemists."

Ciramot and Redfield. Analysis of Water.

Cohn, Alfred I. Indicators and Test Papers.

Evans, P. N. Course in Quantitative Chemical Analysis.

Foulk, C. IV. Notes on Quantitative Chemical Analysis.

Frankland, Percy F. Agricultural Chemical Analysis.

Frescirss. Quantitative Analysis. 2 vols. Translated hy Cohn.

IImlebrand, WT. F. The Analysis of Silicate and Carbonate Rocks.

Bulletin No. 305, United States Geological Survey.

Ingle, H. Manual of Agricultural Chemistry.

Journal of the Association of Official Agricultural Chemists.

LEACH, A. E. Food Inspection and Analysis (3d ed.).

Leffinan and Beam. Select Methods of Food Analysis.

Lincoly and Watton. Elementary Quantitative Chemical Analysis.

Mamin, E. G. Quantitative Analysis.

Morse, H. N. Exercises in Quantitative Analysis.

Olsen, J. C. Pure Foods. 
Olsen, J. C. Quantitative Chemical Analysis (3d ed.).

Ricmuond, II. D. Dairy Chemistry.

Sherman, H. C. Organic Analysis (2d ed.).

SNYDER, H. Dairy Chemistry.

SNYder, H. Soils and Fertilizers.

Sutton, F. Volumetric Analysis (10th ed.).

Talbot, H. P. Quantitative Chemical Analysis.

Treadweld-IIALl. Analytical Chemistry. Vol. II, Quantitative Analysis.

VAN SLyke, I. L. Modern Methods of testing Milk and, Milk Products. 1913.

Wiley, H. W. Foods and their Adulteration. 1913.

WILEY, II. W. Principles and Practice of Agricultural Analysis. Vol. I, "Sirils" (1906) ; Vol. II, "Fertilizers and Insecticides" (1908); Vol. III, "Agricultural Products" (1914).

\section{TABLES OF WEIGH'S}

\section{Metric System}

$$
\begin{aligned}
\text { Milligram } & =0.0154 \text { grain } \\
\text { Gram } & =15.4323 \text { grains } \\
\text { Gram } & =0.03527 \text { ounce avoirdupois } \\
\text { Gram } & =0.0321 \text { ounce troy } \\
\text { Kilogram } & =2.2046 \text { pounds avoirdupois } \\
\text { Kilogram } & =2.6792 \text { pounds troy }
\end{aligned}
$$

\section{Avoirdupois}

Long ton $=2240$ pounds $=1016.047 \mathrm{kilograms}$ Short ton $=2000$ pounds $=907.184$ kilograms

$$
\begin{aligned}
& \text { Pound }=16 \text { ounces }=7000 \text { grains }=453.5924 \text { grams } \\
& \text { Ounce }=437.5 \text { grains }=28.3495 \text { grams } \\
& \text { Grain }=64.798 \text { milligrams }=0.06479
\end{aligned}
$$

\section{Troy}

Pound $=12$ ounces $=5760$ grains $=373.241$ grams

Ounce $=20$ pennyweights $=480$ grains $=31.103$ grams

Pennyweight $=24$ grains $=1.555$ grams

Grain $=64.7989$ milligrams $=0.06479 \mathrm{gram}$

$$
\text { [83] }
$$




\title{
Troy (pharmacy)
}

Ounce $=8$ drams $=480$ grains $=31.1034$ grams

Dram $=3$ scruples $=60$ grains $=3.8879$ grams

Scruple $=20$ grains $=1.295$ grams

\section{TABLES OF MEASURES}

\author{
Length \\ Millimeter $=0.039$ inch \\ Centimeter $=0.393 \mathrm{inch}$ \\ Decimeter $=3.937$ inches \\ Meter $=39.37$ inches \\ Meter $=3.280$ feet \\ Meter $=1.0936$ yards \\ Inch $=2.540$ centimeters \\ Foot $(12$ inches $)=3.0480$ decimeters \\ Yard $(3$ feet $)=0.914$ meter \\ Mile $(1760$ yards $)=5280$ feet \\ Mile (1.609347 kilometers $)=1609.347$ meters
}

\section{Surface}

Square millimeter $=0.00155$ square inch

Square centimeter $=0.1549$ square inch

Square decimeter $=15.499$ square inches

Square decimeter $=0.1076$ square foot

Square meter $=1549.997$ square inches

Square meter $(10.764$ square feet $)=1.195$ square yards

\section{Volume}
Gallon (U.S.) = 231 cubic inches
Gallon (U.S.) $=3.785$ liters
Quart (U.S.) $=0.946$ liter
Pint (U.S.) $=0.473$ liter
Liter (U.S.) $=2.113$ pints (U.S.)
$=1.0566$ quarts (U.S.)
$=0.264$ gallon (U.S.)
Cubic meter $=1.307$ cubic yards
$=35.314$ cubic feet

An imperial gallon (English) $=4.545$ liters

$=277.410$ cubic inches (U.S.)

[84] 
STRENGTH OF HCl SOLUTION AT DIFFERENT DENSITIES, $15^{\circ} \mathrm{C}$.

\begin{tabular}{|c|c|c|c|c|c|}
\hline $\begin{array}{l}\text { SPECIFIC } \\
\text { GRAVITY }\end{array}$ & $\begin{array}{c}\text { Per Cent } \\
\text { OF HCl }\end{array}$ & $\begin{array}{l}\text { GRAMS HCl } \\
\text { IN } 100 \mathrm{ce} \text {. }\end{array}$ & $\begin{array}{l}\text { SPECIFIC } \\
\text { GRAVITY }\end{array}$ & $\begin{array}{l}\text { Per cent } \\
\text { OF } \mathrm{HCl}\end{array}$ & $\begin{array}{l}\text { GRAMS HCl } \\
\text { IN } 100 \mathrm{ec} \text {. }\end{array}$ \\
\hline 1.095 & 19.06 & 20.9 & 1.150 & 29.57 & 34.0 \\
\hline 1.100 & 20.01 & 22.0 & 1.155 & 30.55 & 35.3 \\
\hline 1.105 & 20.97 & 23.2 & 1.160 & 31.52 & 36.6 \\
\hline 1.110 & 21.92 & 24.3 & 1.165 & 32.49 & 37.9 \\
\hline 1.115 & 22.86 & 25.5 & 1.170 & 33.46 & 39.2 \\
\hline 1.120 & 23.82 & 26.7 & 1.175 & 34.42 & 40.4 \\
\hline 1.125 & 24.78 & 27.8 & 1.180 & 35.39 & 41.8 \\
\hline 1.130 & 25.75 & 29.1 & 1.185 & 36.31 & 43.0 \\
\hline 1.135 & 26.70 & 30.3 & 1.190 & 37.23 & 44.3 \\
\hline 1.140 & 27.66 & 31.5 & 1.195 & 38.16 & 45.6 \\
\hline 1.145 & 28.61 & 32.8 & 1.200 & 39.11 & 46.9 \\
\hline
\end{tabular}

STRENGTII OF $\mathrm{I}_{2} \mathrm{SO}_{4}$ SOLLTION A'T DIFFERENT DENSITIES, $15^{\circ} \mathrm{C}$.

\begin{tabular}{c|c|c||c|c|c}
\hline $\begin{array}{c}\text { SPECIFIC } \\
\text { GRAVITY }\end{array}$ & $\begin{array}{c}\text { PER CENT } \\
\text { OF } \mathrm{H}_{2} \mathrm{SO}_{4}\end{array}$ & $\begin{array}{c}\text { GRAMS } \mathrm{H}_{2} \mathrm{SO}_{4} \\
\text { IN } 100 \mathrm{CC} .\end{array}$ & $\begin{array}{c}\text { SPECIFIC } \\
\text { GR.AVITY }\end{array}$ & $\begin{array}{c}\text { PER CENT } \\
\text { OF } \mathrm{H}_{2} \mathrm{SO}_{4}\end{array}$ & $\begin{array}{c}\text { GRAMS } \mathrm{H}_{2} \mathrm{SO}_{4} \\
\text { IN } 100 \mathrm{CC} .\end{array}$ \\
\cline { 1 - 2 } 1.700 & 77.17 & 131.2 & 1.790 & 85.70 & 153.4 \\
1.710 & 78.04 & 133.4 & 1.800 & 86.90 & 156.4 \\
1.720 & 78.92 & 135.7 & 1.810 & 88.30 & 159.8 \\
1.730 & 79.80 & 138.1 & 1.820 & 90.02 & 163.9 \\
1.740 & 80.68 & 140.4 & 1.825 & 91.00 & 166.1 \\
1.750 & 81.56 & 142.7 & 1.830 & 92.10 & 168.5 \\
1.760 & 82.44 & 145.1 & 1.835 & 93.43 & 171.3 \\
1.770 & 83.32 & 147.5 & 1.840 & 95.60 & 175.9 \\
1.780 & 84.50 & 150.4 & & & \\
\hline
\end{tabular}




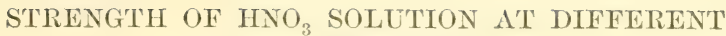
DENSITIES, $15^{\circ} \mathrm{C}$.

\begin{tabular}{|c|c|c|c|c|c|}
\hline $\begin{array}{l}\text { SPECIFIC } \\
\text { GRAVITY }\end{array}$ & $\begin{array}{c}\text { PER CENT } \\
\text { OF } \mathrm{HNO}_{3}\end{array}$ & $\begin{array}{l}\text { GirAMS } \mathrm{HNO}_{3} \\
\text { IN } 100 \mathrm{CC} \text {. }\end{array}$ & $\begin{array}{l}\text { SPECIFIC } \\
\text { GRAVITY }\end{array}$ & $\begin{array}{c}\text { PER CENT } \\
\text { OF } \mathrm{HNO}_{3}\end{array}$ & $\begin{array}{l}\text { GRAMS } \mathrm{HNO}_{3} \\
\text { IN } 100 \mathrm{CC} \text {. }\end{array}$ \\
\hline 1.20 & 32.36 & 38.8 & 1.37 & 59.39 & 81.4 \\
\hline 1.21 & 33.82 & 40.9 & 1.38 & 61.27 & 84.6 \\
\hline 1.22 & 35.28 & 43.0 & 1.39 & 63.23 & 87.9 \\
\hline 1.23 & 36.78 & 45.2 & 1.40 & 65.30 & 91.4 \\
\hline 1.24 & 38.29 & 47.5 & 1.41 & 67.50 & 95.2 \\
\hline 1.25 & 39.82 & 49.8 & 1.42 & 69.80 & 99.1 \\
\hline 1.26 & 41.34 & 52.1 & 1.43 & 72.17 & 103.2 \\
\hline 1.27 & 42.87 & 54.4 & 1.44 & 74.68 & 107.5 \\
\hline 1.28 & 44.41 & 56.8 & 1.45 & 77.28 & 112.1 \\
\hline 1.29 & 45.95 & 59.3 & 1.46 & 79.98 & 116.8 \\
\hline 1.30 & 47.49 & 61.7 & 1.47 & 82.90 & 121.9 \\
\hline 1.31 & 49.07 & 64.3 & 1.48 & 86.05 & 127.4 \\
\hline 1.32 & 50.71 & 66.0 & 1.49 & 89.60 & 133.5 \\
\hline 1.33 & 52.37 & 69.7 & 1.50 & 94.09 & 141.1 \\
\hline 1.34 & 54.07 & 72.5 & 1.51 & 98.10 & 148.1 \\
\hline 1.35 & 55.79 & 75.3 & 1.52 & 99.67 & 151.5 \\
\hline 1.36 & 57.57 & 78.3 & & & \\
\hline
\end{tabular}

STRENGTH OF $\mathrm{NH}_{4} \mathrm{OH}$ SOLUTION AT DIFFERENT DENSITIES, $15^{\circ} \mathrm{C}$.

\begin{tabular}{|c|c|c|c|c|c|}
\hline $\begin{array}{l}\text { SPECIFIC } \\
\text { GRAVITY }\end{array}$ & $\begin{array}{l}\text { PER CENT } \\
\text { OF } \mathrm{NH}_{3}\end{array}$ & $\begin{array}{c}\text { GTAMIS } \mathrm{NH}_{3} \\
\text { IN } 100 \mathrm{CC} \text {. }\end{array}$ & $\begin{array}{l}\text { SPECIFIC } \\
\text { GRAVITY }\end{array}$ & $\begin{array}{l}\text { PER CENT } \\
\text { OF } \mathrm{NH}_{3}\end{array}$ & $\begin{array}{l}\text { GRAMS } \mathrm{NH}_{3} \\
\text { IN } 100 \mathrm{CC} \text {. }\end{array}$ \\
\hline .936 & 16.82 & 15.74 & . 16 & 23.03 & 21.09 \\
\hline .934 & 17.42 & 16.27 & .914 & 23.68 & 21.63 \\
\hline .932 & 18.03 & 16.81 & .912 & 24.83 & 22.19 \\
\hline .930 & 18.64 & 17.34 & .910 & 24.99 & 22.74 \\
\hline .928 & 19.25 & 17.86 & .908 & 25.65 & 23.29 \\
\hline .926 & 19.87 & 18.42 & .906 & 26.31 & 23.83 \\
\hline .924 & 20.49 & 18.93 & .904 & 26.98 & 24.39 \\
\hline .922 & 21.12 & 19.47 & .902 & 27.65 & 24.94 \\
\hline .920 & 21.75 & 20.01 & .900 & 28.33 & 25.50 \\
\hline .918 & 22.39 & 20.56 & .898 & 29.01 & 26.05 \\
\hline
\end{tabular}

[ 86 ] 
STRENGTH OF NaOH SOLUTION AT DIFFERENT

DENSITIES, $15^{\circ} \mathrm{C}$.

\begin{tabular}{|c|c|c|c|}
\hline SPECIFIC GIRAVITY & BAUMÉ & PER CEXT OF NaOH & $\begin{array}{c}\text { Grams NaOH } \\
\text { IN } 100 \mathrm{cc} \text {. }\end{array}$ \\
\hline 1.075 & 10 & 6.55 & 7.0 \\
\hline 1.083 & 11 & 7.31 & 7.9 \\
\hline 1.091 & 12 & 8.00 & 8.7 \\
\hline 1.100 & 13 & 8.68 & 9.5 \\
\hline 1.108 & 14 & 9.42 & 10.4 \\
\hline 1.116 & 15 & 10.06 & 11.2 \\
\hline 1.125 & 16 & 10.97 & 12.3 \\
\hline 1.134 & 17 & 11.84 & 13.4 \\
\hline 1.142 & 18 & 12.64 & 14.4 \\
\hline 1.152 & 19 & 13.55 & 15.6 \\
\hline 1.162 & 20 & 14.37 & 16.7 \\
\hline 1.171 & 21 & 15.13 & 17.7 \\
\hline 1.180 & 22 & 15.91 & 18.8 \\
\hline 1.190 & 23 & 16.77 & 20.0 \\
\hline 1.200 & 24 & 17.67 & 21.2 \\
\hline 1.210 & 25 & 18.58 & 22.5 \\
\hline 1.220 & 26 & 19.58 & 23.9 \\
\hline 1.231 & 27 & 20.59 & 25.3 \\
\hline 1.241 & 28 & 21.42 & 26.6 \\
\hline 1.252 & 29 & 22.64 & 28.3 \\
\hline 1.263 & 30 & 23.67 & 29.9 \\
\hline 1.274 & 31 & 24.81 & 31.6 \\
\hline 1.285 & 32 & 25.80 & 33.2 \\
\hline 1.297 & 33 & 26.83 & 34.8 \\
\hline 1.308 & 34 & 27.80 & 36.4 \\
\hline 1.320 & 35 & 28.83 & 38.1 \\
\hline 1.332 & 36 & 29.93 & 39.9 \\
\hline 1.345 & 37 & 31.22 & 42.0 \\
\hline 1.357 & 38 & 32.47 & 44.1 \\
\hline 1.370 & 39 & 33.69 & 46.2 \\
\hline 1.383 & 40 & 34.96 & 48.3 \\
\hline 1.397 & 41 & 36.25 & 50.6 \\
\hline 1.410 & 42 & 37.47 & $\begin{array}{l}52.8 \\
5 . ?\end{array}$ \\
\hline 1.424 & 43 & 38.80 & 55.3 \\
\hline 1.438 & 44 & 39.99 & 57.5 \\
\hline 1.453 & 45 & 41.41 & 60.2 \\
\hline
\end{tabular}




\section{SOLUBILTTIES IN TVATER}

All the chlorides are soluble except those of silver, Irort, and mercurous mercury.

All the sulphates are soluble except those of strontium, barium, and lead.

All the carlonates and phosphates are insoluble except those of sodium, potussium, and ammonium.

All the hydroxides are insoluble exerent those of sorlimm, potassium, ammonium, calcium, strontium, and barium.

All nitrates, acetates, and chlorates are soluble.

\section{DIRECTIONA FOR PREPARATION OF REAGENTS}

\section{Indicators for Volunetric Analysis}

Litmus. Boil 1 g. of purified powdered litmus with 60 \% of distilled watere, filter, and divide filtrate into two equal portions. To one portion adel dilute $\mathrm{I}_{2} \mathrm{~S}()_{4}$, drop by drop, until the solution is just acid. Nix the two portions and keep in a glass-stoppered bottle.

Cochineal. Digest $1 \stackrel{g}{s}$. of rmshed rochineal dregs in 100 ce. of 25 per cent alcohol (he sure the alcohol is neutral) and filter.

Methyl Orange. I)issolve $1 / 10 \mathrm{~g}$. in $100 \mathrm{ce}$ of distilled water.

Methyl Red。Dissolve 1/10 g. in 100 ce. of distilled water.

Phenolphthalein. Dissolve $1 \mathrm{~g}$. in 100 ce of 50 jer cent alcohol.

Corallin. Saturate alcohol (that has previously been made neutral) with corallin.

\section{Solutions for Quantitative Analysis}

Asbestos for Gooch Crucible. Select a good grade of asbestos with long fibers. The asbestos should be separated until the fibers are about one-fourth inch long, then digested with concentrated HC'l for twelve hours, filtered, and washed with distilled water until free from chlorides. Transfer the asbestos to a bottle containing distilled water

$$
\text { [88] }
$$


Silver Nitrate Solution. Dissolve $16.994 \mathrm{~g}$. of silver nitrate $\left(\mathrm{Ag} \mathrm{NO}_{3}\right)$ arystals in $1000 \mathrm{cc}$. of distilled water (free from chlorides) and place in a dark-colored bottle away from the sunlight.

Ammonium Oxalate Solution. Dissolve $42 \mathrm{~g}$. of ammonium oxalate $\left(\left(\mathrm{NH}_{2}\right)_{2} \mathrm{C}_{2} \mathrm{O}_{4} \cdot \mathrm{H}_{2} \mathrm{O}\right)$ in 1000 (c. of distilled water.

\section{Solutions used in the Analysis of Feedstuff}

Saturated Solution of Sodium Hydroxide. Dissolve about $1000 \mathrm{~g}$. of NaOH in 1 liter of water', cool, and pour into a bottle (crude NaOII may be used if the impurities are allowed to settle and the clear solution drawn off for use).

Anhydrous, Alcohol-Free Ether. Let the ether stand in con-

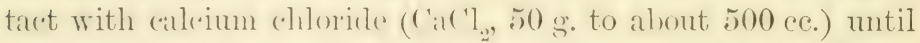
next labolatory perion, and distill, using a distilling tube. Place the distilled ethere in a di!y glass-stoplenered bottle orer metallie sodium free from oil. For a slourt tine leave the bottle loosely stoplered so that the hydhomen evolved may esciple. The ether should be filtererl, or the rlear solution should be drawn off without disturbing the residue.

\section{Solutions used in the Analysis of Soits}

Ammonium Oxalate Solution. Prepared as in I.

Sodium Ammonium Hydrogen Phosphate (Microcosmic Salt). Dissolve $100 \mathrm{~g}$. of solium ammonium hydrogen phospluate $\left(\mathrm{NaNH}_{4} \mathrm{HPO}_{4} \cdot 4 \mathrm{H}_{2} \mathrm{O}\right)$ in 1 liter of distilled water.

Ammonium Molybdate Solution. * Dissolve $100 \mathrm{~g}$. of molylulic arid in 144 ce. of ammonimm hydroxide (sp). gre 0.90) and 271 ce. of water; slowly, and with constant stirring, pour the solution thus olntaines into 489 ( ( . of nitric acisl (sp) gr. 1.42) and 1148 ece of water. Keep the mixture in a warm place for

* Bulletin 10 r (Revised), Bureau of Chemistry, Lnited States Department of Agriculture. 
several days or until a portion heated to $40^{\circ} \mathrm{C}$. deposits no yellow presipitate of ammonimm phosphomolyblate. Derant the solution from any sedinent and preserve in al glass-stoplered bottle.

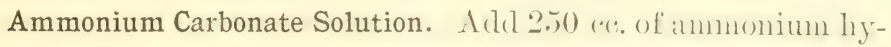
droxide (sp). gr. 0.90$)$ to $250 \mathrm{~g}$. ammonium carbonate $\left(\left(\mathrm{XH}_{4}\right)_{2}(\mathrm{O})_{3}\right)$ and make up to a liter.

Saturated Solution of Sodium Hydroxide. Preprared as in I.

Saturated Solution of Barium Hydroxide. Dissolve about $50 \mathrm{~g}$. of barium hydroxide in 1 liter of water.

Platinum Solution. Dissolve 172.S g. PtC $\mathrm{l}_{4}$ in 1 liter of water. (1 ec. of the solution contains $1 \mathrm{~g}$. of platinum, equivalent to $.21 \mathrm{~g} . \mathrm{H}_{2} \mathrm{Pt}\left({ }^{\prime} \mathrm{l}_{6}{ }^{\circ}\right)$

Solution of Oxalic Acid. Dissolve $3.2 \mathrm{~g}$. of oxalic acid $\left(\mathrm{C}_{2} \mathrm{H}_{2}()_{4} \cdot 2 \mathrm{I}_{2} \mathrm{O}\right)$ in $500(\cdot($ of distilled water contalining 25 ce. of concentrated C. P. $I_{2} \mathrm{KO}_{4}$. Measure out, with a pipette or burette, two $25 \times$ portions into leakers, adel 2 ( $\cdots$ of $\mathrm{I}_{2} \mathrm{~S}()_{4}$ $(1: 1)$, heat to $60^{\circ}($., and titrate with the standard K . .no() solution. Note the volume of KMnO, solution resuired to oxidize completely $1 \mathrm{cc}$. of the oxalic acid solution.

Ammonium Chloride Solution saturated with Potassium Chloroplatinate. Dissolve $100 \mathrm{~g}$. of ammonimu chloride in $500 \mathrm{ce}$ of water, add from 5 to $10 \mathrm{~g}$. of pulverized potassium chloroplatinate (potassium platinie chloride), and shatie at intervals for six or eight hours. Allow the mixture to settle, filter, and use the clear filtrate for the potash determination. The residue may be used for the preparation of a fresh supply.

Cobaltinitrite Reagent.* Dissolve $220 \mathrm{~g}$. of solim nitrite in $400 \mathrm{cc}$. of water and $113 \mathrm{~g}$. of cobalt acetate in $300 \mathrm{ce}$. of water, and add $100 \mathrm{cc}$. of glacial acetic acid. The two solutions are mixed and gently wamed, No, is evolred, and the solution becomes dirts colored. The No, is hest evalluated from the bottle hy a water prump and the liquid left overnight,

* F. Sutton, Volumetric Analysis (9th ed.), p. 62.

$[90]$ 
during which a yellow precipitate settles. The solution is then filtered and diluted with water to 1 liter.

Alcohol Solution. Prepare the alcoliol solution containing 80 per cent alcohol (sp. gr. 8639 at $15^{\circ} \mathrm{C}$.).

Asbestos for Gooch Crucible. Prepared as in I.

IV. Solutions used in the Analysis of Fertilizers

Ammonium Molybdate Solution. Prepared as in III.

Ammonium 0xalate Solution. Prepared as in I.

Ammonium Chloride Solution saturated with Potassium Chloroplatinate. Prepared as in III.

Asbestos for Gooch Crucible. Prepared as in I.

Alcohol Solution ( $80 \%$ ). Prepared as in III.

Cobaltinitrite Reagent. Prepared as in III.

Platinum Solution. Prepared as in III.

Magnesia Mixture. Weigh out 11 of ofeently ignited calcined magnesia and dissolve in dilute hrdrochloric ar.id, aroiding an excess. Ard a little exerss of magnesia and boil to precipitate iron, almmina, and phosphoric: arid. Filter, add $140 \mathrm{~g}$. ammonimm chloride and 180.5) g. of ammonimm hydroxide (sp. gre. .9), and dilute to 1 liter. Instead of the caleined magnesia, $55 \mathrm{~g}$. of crystallized magnesium chloricle $\left(\mathrm{MgCl}_{2} \cdot 6 \mathrm{H}_{22} \mathrm{O}\right)$ may be used.

Salicylic Acid Solution. Adel $1 \mathrm{~g}$. salierlic ac.iel to $30 \mathrm{ce}$. $\mathrm{H}_{2} \mathrm{SO}_{4}$. Shake until thoroughly mixed, and allow it to stand from five to ten minutes, with frequent shakings.

Ammonium Citrate Solution.* Dissolve 370 g. of commercial citric acid in 1500 c.. of water; nearly neutralize with

* Hall, Journal of Industrial and Engincering Chemistry, Vol. III (1911), p. 559) ; Rudnick, Joumal of Industrial und Engineeriny ('7emistry. Tol. V (1913), pp. 12, 998 ; E. D. Eastman and J. H. Hildebrand, Journal of Industrial and Engineering Chemistry. Vol. VI (1914), p. 578; Hall, Journal of Ameriren Chemicul soriety, Vol. XXXVII (Jannary, 1915), p. 208. Bulletin 10\% (Revised), Bureau of Chemistry, United States Department of Agriculture. 
commeredal ammonium hychoxile; cool ; add ammonium hydroxide until exactly neutral (testing with saturated alcologlic solution of (corallin); and dilute to a volume of 2 liters. I)etermine the specitic gravity, which should be 1.09 at $20^{\circ} \mathrm{C}$.

\section{Solutions used in the Analysis of Insecticides}

Alcohol Solution (95\% $\mathrm{C}_{2} \mathrm{H}_{5} \mathrm{OH}$ by Volume). Preprare a solution of alcohol whose specific gravity is .8164 at $15^{\circ} \mathrm{C}$.

Potassium Ferrocyanide Solution. I)issolve St g. of potassium ferrocyanide $\left(\mathrm{K}_{4} \mathrm{Fe}(\mathrm{Cn})_{6}\right)$ in 1 liter of distilled water.

\section{Solutions used in the Analysis of Milk}

Anhydrous, Alcohol-Free Ether. Preprated ats in II.

Saturated Sodium Hydroxide Solution. Prepared as in II.

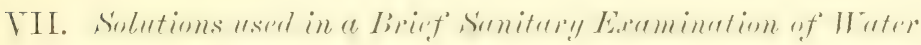

Potassium Chromate Solution (Indicator). I)issolve 10 of of

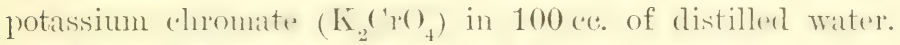

Nessler's Reagent.* I)issolve (i2.5) g. of potassium iodicle in about 250 (' of of tistilled water, set aside a few cullic centineters, and ack gradually to the larger prert a cold saturated solution of mereuric rhloriste (of which about 500 e. will be repuired) until the mereurie iodide precipitated reases to redissolve on stirring. When a permanent precipitate is retained, restore the reserved potassium iodide so as to redissolve it, and contimue adeling mereuric rhloride very sralually until a slight precipitate remains undissolverl. (The small quantity of potassium iodide is set aside merely to enathe the mixture to be made rapidly without danger of adding an exeess of mereury.) Next dissolve $150 \mathrm{~g}$. of potassium hychexile in 1.50 ("e clistilled water, allow the solution to cool, adil it gralually to the aloove solution, and make up with distilled water to 1 liter.

* F. Sutton, Volumetric Analysis (10th ed.), p. 437. 
On standing, a brown precipitate is deposited and the solution becomes clear and of a prale greenish-yellow color. It is ready for use as soon as it is completely clear, and should be decanted into a smaller bottle as required. The reagent improves on keeping.

Sulphanilic Solution. T)issolve .S g. of the acid in $100 \mathrm{ec}$. of distilled water, heating if necessary.

Naphthylamine Hydrochloride Solution. I)issolve .S g. of the salt in $100 \mathrm{ec}$. of hot distillere water to which 1 \% of IICl has been adderl. Filter through hone black, or atd bone black to the solution, and decant as needed. Kexer) away from the light.

Phenolsulphonic Acid. Mix :30 of phenol with 210 (“e or $370 \mathrm{~g}$. of concentrated $\mathrm{H}_{2},{ }()_{4}$ in a flask. Plate the flask in a water bath so that the surfare of the lingicl in the flask will be below the water. In art for six homs at the temperature of boiling water.

\section{APPARATUS FOR DESK EQUIPMENT}

4 beakers: two $200 \mathrm{cc}$.; two $350 \mathrm{cc}$.

5 bottles: two $500 \mathrm{cc}$; two $1000 \mathrm{cc}$.; one $250 \mathrm{cc}$. (wide-mouthed).

2 Bunsen burners with $4 \mathrm{ft}$. of rubber tubing.

2 burettes, complete.

1 burette holder.

1 condenser with clamp.

1 crucible tongs.

2 crucibles, porcelain, No. 7, with covers.

2 crucibles, Gooch.

1 cylinder, graduated, $50 \mathrm{cc}$.

1 desiceator, complete.

2 evaporating dishes, No. 4.

25 filter papers, $9 \mathrm{~cm}$.

1 flask, 500 ce. with rubber stopper for wash bottle.

4 flasks, Erlenmeyer : two $250 \mathrm{cc}$.; two $500 \mathrm{ce}$.

2 flasks, Kjeldahl digestion: $800 \mathrm{cc}$.
2 flasks, measuring: one $250 \mathrm{cc}$; one 500 cc.

1 flask, filtering.

5 fummels: four $50 \mathrm{~mm}$.; one Gooch.

1 funnel holder, wood.

Matches, safety, 1 box.

2 pipettes: one $25 \mathrm{cc}$; one $50 \mathrm{cc}$.

2 rings, iron, 3 -inch.

4 rods, glass.

1 stand, iron.

6 test tubes, $10 \mathrm{~cm}$.

1 test-tube brush.

1 test-tube rack.

1 thermometer, $100^{\circ} \mathrm{C}$.

'Towel or one-half yard absorption cloth.

2 triangles, pipestem.

Tubing, glass, for wash bottle.

4 watch glasses: one $35 \mathrm{~mm}$.; one $50 \mathrm{~mm}$.; one $62 \mathrm{~mm}$.; one $80 \mathrm{~mm}$. 


\section{INTERNATIONAL ATOMIC WEIGHTS (1916)}

\section{Abridged Table}

\begin{tabular}{|c|c|c|c|c|c|c|c|c|c|c|}
\hline ELE: & & & & SymboL & $\begin{array}{l}\text { Atonic } \\
\text { Weight }\end{array}$ & Element & & & SYMBOL & $\begin{array}{r}\text { A TOMIC } \\
\text { WEIGHT }\end{array}$ \\
\hline Aluminium & & . & 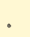 & . $\mathrm{Al}$ & 27.10 & Lithium . & & . & . $\mathrm{Li}$ & 6.94 \\
\hline mony & & 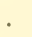 & & . $\mathrm{Sb}$ & 120.20 & nesium & . & 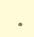 & . $\mathrm{Mg}$ & 24.32 \\
\hline nnic . & 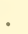 & . & . & . As & 74 & anese & . & 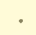 & . $\mathrm{Mn}$ & 54.93 \\
\hline um . & . & . & . & - $\mathrm{Ba}$ & 137 & ary . & . & $\cdot$ & . $\mathrm{Hg}$ & 200.6 \\
\hline Bismuth . & 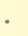 & . & . & - $\mathrm{Bi}$ & 208 & Molybdenum & n & 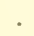 & . Mo & 96.0 \\
\hline Boron & ${ }^{\circ}$ & . & - & . $\mathrm{B}$ & & el. & 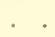 & 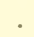 & . $\mathrm{Ni}$ & 58.68 \\
\hline ine. & . & 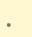 & & . $\mathrm{Br}$ & & ggen . & . . & & . $\mathrm{N}$ & \\
\hline m . & . & . & & - $\mathrm{Cal}$ & & $n$. & . . & . & .0 & 16 \\
\hline $\mathrm{Ca}$ & & . & & . $\mathrm{C}$ & & horus & . & - & . P & \\
\hline ne. & . & . & . & . $\mathrm{Cl}$ & & $\mathrm{m}$ & . & & - I't & 19 \\
\hline ium & . & 。 & . & . $\mathrm{Cr}$ & 5 & sium & . & 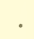 & . Ki & 39.10 \\
\hline Cobalt. & . & 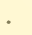 & . & . $\mathrm{Co}_{0}$ & & n. & . & & . Si & 30 \\
\hline $\mathrm{er}$ & . & . & & . $\mathrm{Cu}$ & & Sil & . & & . $\lambda g$ & $10^{7}$ \\
\hline rine & 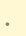 & 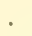 & & . $\mathrm{F}$ & & Sor & . & • & - Na & 23.00 \\
\hline . . & 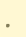 & . & & . Ai & 197 & ium & . & & . $\mathrm{Sr}$ & 87.63 \\
\hline rogen & . & . & • & . $\mathrm{II}$ & & phur . & . & & . $S$ & 06 \\
\hline Ioc & . & . & • & . I & 126 & & . & & . $S_{1}$ & 118.70 \\
\hline . . & 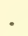 & . & . & . $\mathrm{Fe}$ & & Uranium . & . & & . U & 238.20 \\
\hline Lead . . & . & . & & - $\mathrm{Pb}$ & 207.20 & Zinc. . & & & - $\mathrm{Zn}$ & 65.37 \\
\hline
\end{tabular}





\section{ANNOUNCEMENTS}





\section{RECENT BOOKS ON AGRICULTURE}

\section{LABORATORY MANUAL OF HORTICULTURE}

By GEoRge W. Hood, University of Nebraska. 234 pages, illustrated, \$r.oo.

ExERCISES on seeding and seed testing, principal methods of propagation (cutting, budding, grafting, etc.), differentiating between branch and fruit buds of the different fruits, pruning, manufacture of insecticides and fungicides (with something of the chemistry underlying these operations), and analysis and comparative study of the principal fruits, including the description, identification, and value of some of the most important varieties.

\section{MANUAL OF SOIL PHYSICS}

By Percy B. Barker, University of Missouri, and H. J. Young, University of Nebraska. ${ }_{4}$ Exercises, with blank pages for notes, in Biflex Binder, 65 cents.

A COMPLETE set of exercises for laboratory work in soils, affording a comprehensive survey of the whole subject. The exercises give the student an understanding of the origin of the soil; soil water, its movements, use, and conservation; soil heat; the texture and structure of the soil; organic matter, its effect upon the physical condition of the soil and its influence upon productiveness. The study includes exercises in some of the more simple and practical methods of soil examination.

\section{A MANUAL OF BACTERIOLOGY}

\section{For Agricultural and Domestic-Science Students}

By Howard S. Reed, Agricultural Experiment Station, Riverside, Cal. xii +179 pages, illustrated, $\$ \mathbf{r} .25$.

Experiments which give the student a first-hand knowledge of the principles and processes concerned in the bacteriology of such subjects as water, soils, milk, plant disease, and yeast and other organisms concerned in food fermentations. The manual contains full directions for the preparation of culture media, and for staining, sterilization, and other manipulations.

\section{LABORATORY MANUAL OF AGRICULTURAL CHEMISTRY}

By Charles Cleveland Hedges and William Thoreau Bryant, Texas Agricultural and Mechanical College. [I $n$ press]

SIXTY-THREE exercises organized under the following heads: Preparatory Quantitative Analysis, Analysis of Feedstuffs, Chemical Analysis of Soils, Analysis of Fertilizers, Analysis of Insecticide and Fungicide, Analysis of Milk, Sanitary Examination of Water. 


\section{COUNTRY LIFE EDUCATION SERIES}

A SERIES of practical texts for the student and the professional farmer, written by experts in their respective lines. These books aim to give a thorough exposition of both the theory and the practice of the various branches of farming and breeding.

\section{TYPES AND BREEDS OF FARM ANIMALS}

By Charles S. Plumb, Professor of Animal Husbandry in the College of Agriculture, Ohio State University. $5_{6} 3$ pages, illustrated, $\$ 2.00$.

\section{PRINCIPLES OF BREEDING}

By Eugene Davenport, Dean of the College of Agriculture, Director of the Agricultural Experiment Station, and Professor of Thremmatology in the University of Illinois. 727 pages, illustrated, $\$ 2.50$.

\section{FUNGOUS DISEASES OF PLANTS}

By Benjamin Minge Duggar, in charge of Graduate Laboratory, Missouri Botanical Garden, St. Louis. 508 pages, illustrated, \$2.00.

SOIL FERTILITY AND PERMANENT AGRICULTURE, By Cyril George Horkins, Professor of Agronomy in the University of Illinois; Chief in Agronomy and Chemistry and Vice Director in the Illinois Agricultural Experiment Station. xxiii +653 pages, $\$ 2.25$.

PRINCIPLES AND PRAC'TICE OF POULTRY CULTURE By John H. Robinson, Editor of Farm-Poultry. xvi +6 I pages, illustrated, $\$ 2.50$.

\section{GARDEN FARMING}

By Lee Cleveland Corbett, Horticulturist in the Bureau of Plant Industry, United States Department of Agriculture. 462 pages, illustrated, \$2.00.

\section{THE APPLE}

By Albert E. Wilkinson, of the Department of Horticulture in Cornell University. 492 pages, illustrated, \$2.00.

EQUIPMENT FOR THE FARM AND THE FARMSTEAD By Harry C. Ramsower, Professor of Agricultural Engineering in Ohio State University. [In press]

\section{Other volumes in preparation}

\section{GINN AND COMPANY Publishers}




\section{BOOKS ON AGRICULTURE}

\section{SHEEP FEEDING AND FARM MANAGEMENT}

By D. Howard DoAne, Assistant Agriculturist in the Office of Farm Management,

United States Department of Agriculture, and Assistant Professor, in charge, of Farm

Management in the University of Missouri. 12mo, cloth, r28 pages, illustrated, \$1 .00.

A PRACTICAL manual on the feeding of sheep for market, embodying the experience of successful sheep men and farmers throughout the country. As a textbook for classes in farm management, animal husbandry, and agronomy, the book contains much useful material.

\section{SOIL PHYSICS LABORATORY MANUAL}

By J. G. Mosier, Professor of Soil Physics, and A. F. Gustafson, Associate in Soil Physics, in the University of Illinois. 8vo, cloth, $7 \mathrm{r}$ pages, illustrated, 6o cents.

Practices designed to give the student a knowledge of the physical principles that underlie the common agricultural operations. Many of these practices are here published for the first time. An appendix contains work for advanced students.

\section{EXAMINING AND GRADING GRAINS}

By Thomas L. Lyon, Professor of Soil Technology in the Federal Experimental Station, Cornell University, and Edward G. Montgomery, recently Assistant Professor of Experimental Agronomy in the University of Nebraska. 12mo, cloth, Ior pages, illustrated, 6 c cents.

Text and exercises providing a thorough drill in the study of the structure and quality of all cereals, in the identification of seeds of the common grasses, millets, and legumes, and in judging the quality of hay of these crops.

\section{EXPERIMENTAL DAIRY BACTERIOLOGY}

By H. L. Russell, Dean of the College of Agriculture, and E. G. Hastings, Associate Professor of Agricultural Bacteriology in the University of Wisconsin. 12mo, cloth, I 47 pages, illustrated, \$r.oo.

A STUDY of the bacteriological processes which must be understood before the relation of microörganisms to dairy processes can be appreciated. This guide will be found equally valuable for the student and for the practical worker.

\section{PRINCIPLES OF RURAL ECONOMICS}

By Thomas Nixon Carver, David A. Wells Professor of Political Economy in Harvard University. 8vo, cloth, $\mathrm{xx}+386$ pages, $\$ \mathbf{I} .30$.

CHAPTERS on the history of agriculture, the factors of agricultural production, farm management, agricultural coöperation, the distribution of the agricultural income, and the problems of rural social life are among those included in this book. 


\section{TEXTBOOKS IN PHYSICS AND CHEMISTRY FOR HIGH SCHOOLS AND COLLEGES PHYSICS}

Cavanagh, Westcott, and Twining: Physics Laboratory Manual \$0.70 IIastings and Beach : Textbook of General Physics . . . . . 2.75 Higgins: Lessons in Physics . . . . . . . . . . . . . 90

IIiggins: Simple Experiments in Physics . . . . . . . . .35

Hill: Essentials of Physics . . . . . . . . . . . I.IO

Ingersoll and Zobel: Mathematical Theory of IIeat Conduction r.6o

Jeans: Theoretical Mechanics . . . . . . . . . 2.50

Miller: Laboratory Physics . . . . . . . . . . . . . 2.00

Millikan: Mechanics, Molecular Physics, and IIeat . . . . . I.50

Millikan and Gale: First Course in Physics (Rev. Ed.) . . . . I.25

Millikan, Gale, and Bishop: First Course in Laboratory I'hysics $\quad .50$

Millikan and Mills : Electricity, Sound, and Light . . . . . . 2.00

Mills: Introduction to Thermodynamics . . . . . . . . 2.00

Packard : Everyday Physics . . . . . . [ [n press $]$

Sabine: Laboratory ('ourse in Physical Measurements . . . . I.25

Smith, Tower, and Turton: Manual of Experimental Physics . . . So

Snyder and Palmer: One Thousand Problems in Physics . . . .50

Stone: Experimental Physics . . . . . . . . . . I.00

Wentworth and 1Iill: Textbook in Physics (Rev. Ed.) . . . I.I5

Wentworth and Hill: Laboratory Exercises (Rev. Ed.). . . . .25

\section{CHEMISTRY}

Allyn : Elementary Applied Chemistry . . . . . . . . . .60

Dennis and Whittelsey: Qualitative Analysis (Rev. Ed.) . . 1.00

Evans: Quantitative Chemical Analysis . . . . . . . . . 50

McGregory: Qualitative (hemical Analysis (Rev. Ed.). . . . I.00

McPherson and Henderson : Course in General Chemistry . . 2.25

McPherson and Henderson: First Course in Chemistry . . . I.25

McPherson and IIenderson: Laboratory Exercises in Chemistry .40

McPherson and Henderson: Laboratory Manual for General

Chemistry

Moore: Logarithmic Reduction Tables _.. . . . . . I.00

Morse: Exercises in Quantitative Chemistry . . . . . . 2.00

Nichols: Laboratory Manual of Household Chemistry [ $1 n$ press]

Olsen: Pure Foods: Their Adulteration, Nutritive Value, and Cost

Ostwald and Morse: Elementary Modern Chemistry . . . . 1.00

Sellers: Treatise on Qualitative Analysis (Rev. Ed.) . . . . 1.00

Thorp: Inorganic Chemical Preparations . . . . . . . I.50

Unger: Review Questions and Problems in Chemistry . . . . .50

Williams: Chemical Exercises . . . . . . . . . . 30

Williams : Essentials of Chemistry . . . . . . . 1.25

Williams : Laboratory Manual of General Chemistry . . . . . $\quad .25$ 



\section{LIBRARY OF CONGRESS

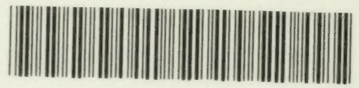 00026?18739}

